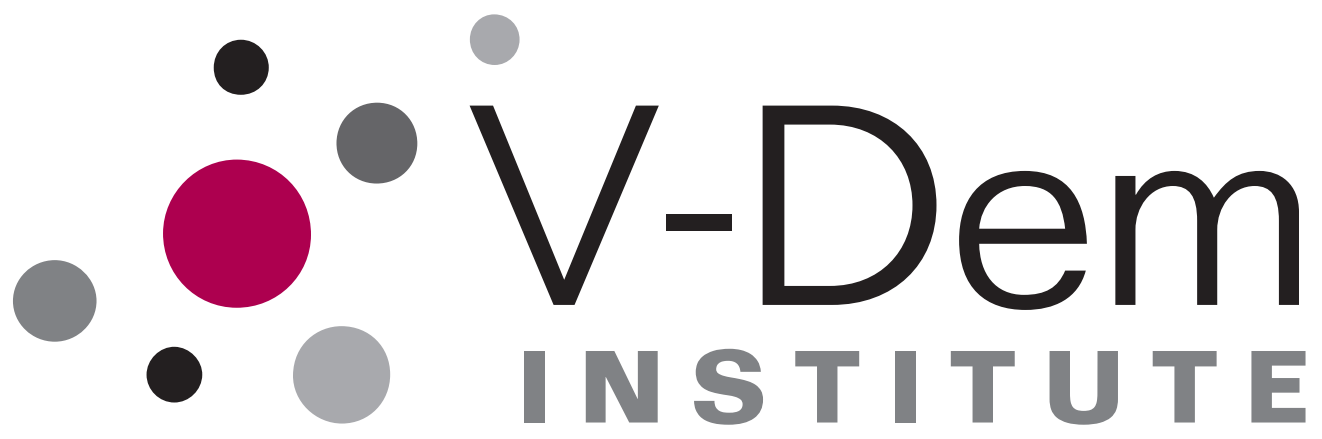

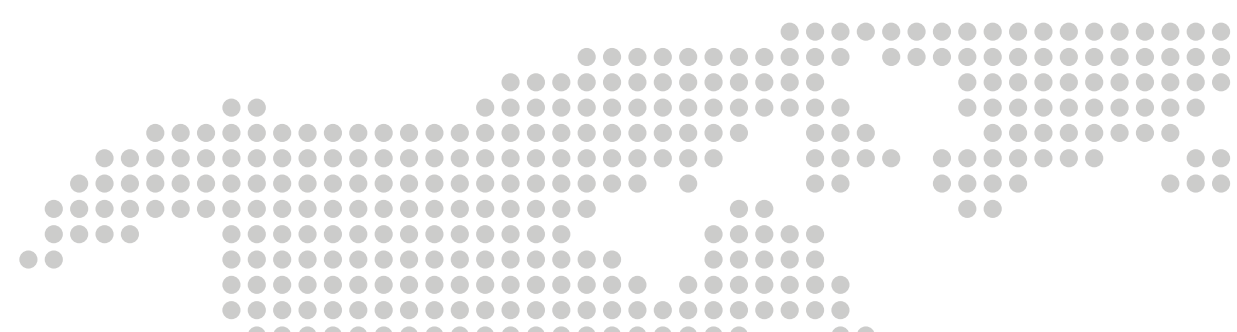

00
000
000
000

$$
100
$$

909098

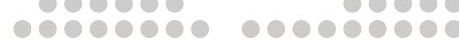
$000000000000000 \mathrm{c}$

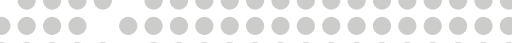
 -

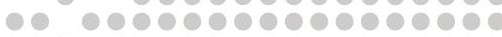

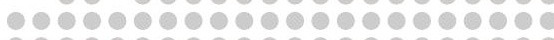

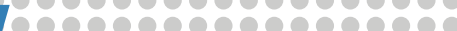

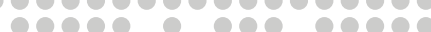
1000

The Long March: Deep Democracy in Cross-National Perspective

Mohammad Ali Kadivar, Adaner Usmani, Benjamin Bradlow

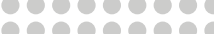

0009000

0099000

resere

reser

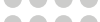

1000

000

10

10

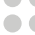

8

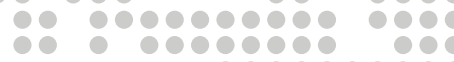

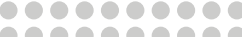

1000 00000000000000

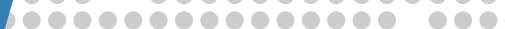

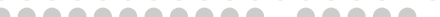

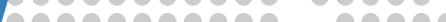

68980

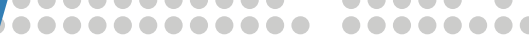

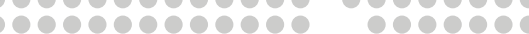
1000000000000000000

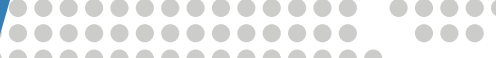
1000000000000000

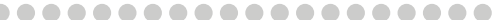
100000000000000000000 20000000000000000

-



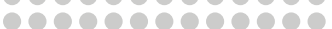

10000000000

00000000000

000000000

o

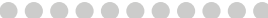

09000000000

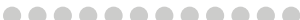

000000000

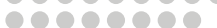

00000000

000000

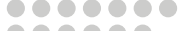

- 0000

000

100

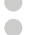

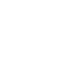

10

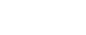

March 2019 
Varieties of Democracy (V-Dem) is a new approach to conceptualization and measurement of democracy. It is co-hosted by the University of Gothenburg and University of Notre Dame. With a V-Dem Institute at University of Gothenburg with almost ten staff, and a project team across the world with four Principal Investigators, fifteen Project Managers (PMs), 30+ Regional Managers, 170 Country Coordinators, Research Assistants, and 2,500 Country Experts, the V-Dem project is one of the largest ever social science research-oriented data collection programs.

Please address comments and/or queries for information to:

V-Dem Institute

Department of Political Science

University of Gothenburg

Sprängkullsgatan 19, PO Box 711

SE 40530 Gothenburg

Sweden

E-mail: contact@v-dem.net

V-Dem Users Working Papers are available in electronic format at www.v-dem.net.

Copyright (C) 2019 by authors. All rights reserved.

Disclaimer: V-Dem does not do quality control and therefore does not endorse the content of the papers, which is the responsibility of the authors only. 


\title{
The Long March: Deep Democracy in Cross-National Perspective
}

\author{
Mohammad Ali Kadivar \\ Assistant Professor \\ Department of Sociology, Boston College \\ Adaner Usmani \\ Postdoctoral Fellow \\ Watson Institute for International and Public Affairs, Brown University \\ Benjamin H. Bradlow \\ $\mathrm{PhD}$ Candidate \\ Department of Sociology, Brown University
}




\begin{abstract}
Over the last several decades, dozens of dictatorships have become democracies. Yet while each has held free and fair elections, they have varied in the extent to which their citizens realize the ideal of self-rule. Why do some democracies distribute power to citizens while other democracies withhold it? Existing research is suggestive, but its implications are ambiguous. Cross-national studies have focused on democracy's formal dimensions, while work on substantive democracy is case-based. We find that one of the most consistent and powerful explanations of substantive democratization is the length of unarmed pro-democratic mobilization prior to a transition. Through a case study of Brazil, we illustrate that these movements matter in three ways: first, because practices of self-organizing model and enable democratic reforms; second, because movement veterans use state office to deepen democracy; and third, because long movements yield civil societies with the capacity to demand the continuous deepening of democracy.
\end{abstract}




\section{Introduction}

Over the last two centuries, countries across the world have transitioned from authoritarian rule. By any of the long-run indices available, democracy has spread far and wide. Despite evidence of democratic erosion in recent years, ${ }^{1}$ the world over the last few decades has never been more democratic than it is now.

Yet while democracies exist everywhere, they do not everywhere exist equally. Beneath the veneer of formal democracy lies substantial variation in the extent to which citizens realize the ideal of self-rule. This is puzzling. At its heart, the democratic ideal promises people equal influence over political decisions. Given this, why do some democracies distribute power to citizens while other democracies withhold it? What explains why formal democracies exhibit variation in substantive democratization?

The literature on democracy is enormous but marked by a disconnect. Cross-national studies of democracy have focused on its formal dimensions. By this we mean that scholars have studied the degree to which democracies hold fair and free elections, and the degree to which they safeguard individual rights. In doing so, they have neglected the other dimensions of the democratic ideal - the extent to which disadvantaged citizens have gained real equality and the ability to participate in the policy process. Conversely, those who have studied substantive democracy have relied on case studies or comparative analyses.

In this paper, we bring these studies together by presenting the first cross-national study of substantive democratization. We rely on recent advances in the measurement of various dimensions of democracy by the Varieties of Democracy project, which enable scholars to study patterns in substantive democracy directly. We derive our hypotheses from cross-national studies of formal democratization as well as qualitative work on substantive democratization. To test these rival explanations, we use a dataset consisting of formally democratic regimes observed after 1950, where a formal democracy is a regime in which executive power is transferred through fair and free multiparty elections.

\footnotetext{
1 The extent of this erosion depends on which index is used to assess it, but it is by no measure very large. By V-Dem's electoral democracy index, which we introduce later in this paper and is today considered the gold standard, the decline between 2012 and 2017 amounts to just 2.5\% of the progress made between 1789 and 2012.
} 
We find that one of the most consistent explanations of variation in substantive democracy is the length of unarmed pro-democratic mobilization prior to a democratic transition. This is not the only explanation our evidence supports, but it is one of the most consistent and powerful.. We build on recent work by Klein and Lee (forthcoming) and a case study of Brazil to argue that these movements matter in three ways: first, because movement practices of self-organizing model and enable the reform of state institutions; second, because veterans of the pro-democracy movement are more likely to use state office to deepen democracy; third, because long movements give posttransition civil societies the capacity to demand the continuous deepening of democracy. In an era of anxiety about the antidemocratic proclivities of the mass public, our results are a reminder that ordinary people have advanced the cause of democracy and not hindered it.

\section{Literature Review}

The rise of democracy is one of the most well-studied subjects in the social sciences. Scholars, ancient and modern, have long sought to understand why divided societies would grant otherwise unequal citizens equal standing. This is a puzzle of first-order importance, and we have learned a tremendous amount from the scholarship on this subject to date.

Yet there is an evident dichotomy in the literature. Cross-national research has focused on formal aspects of democracy. Indeed, even studies of democratic quality define quality in formal terms: competitive elections and laws safeguarding individual rights to free expression and assembly (for a critical review, see Fishman 2016).

Of course, not all formal democracies empower their citizens equally. And this fact cuts to the heart of why democracy matters. In their survey of democratizations past and present, Rueschemeyer et al. observed that democracy is important because it defies the ordinary distribution of power in divided societies. As a rule, those with "less income, less wealth, less education and less honor" have had little power in human history. But democracy is a "counterintuitive state of affairs" which gives the disadvantaged "a real voice" (1992:41). Similarly, as Robert Dahl has argued, the ideal democracy achieves real political equality. In a fully democratic regime, citizens acquire equal capacities to shape the political agenda (Dahl 1972:8,90, 2006:2). 
The scholarship that has focused on this aspect of democracy typically refers to this redistribution of power as democratic deepening. These scholars investigate whether the idea of popular self-rule is achieved, and specifically whether disadvantaged groups gain leverage over the policy process. In this view, representation is not sufficient. (Fishman 2016:303-5). Democracies also require institutions that promote the participation of citizens in decision-making (Barber 2004), and a public sphere through which citizens engage in a conversation about the major affairs of the polity (Gutmann and Thompson 2004). Accordingly, scholars of democratic deepening emphasize the importance of participatory institutions (Fung and Wright 2003), deliberation in the public sphere (Baiocchi 2003), and redistributive programs that ensure equal voice for disadvantaged groups (Roberts 1998). Yet the empirical work on these is still thin, resting on case studies or comparative analysis of a few cases (Baiocchi, Heller, and Silva 2011; Heller 2000; Roberts 1998).

Given the state of the literature, we are left with some unknowns. We do not know if arguments developed at the cross-national level but limited to formal dimensions extend to substantive dimensions. Nor do we know whether qualitative work on democratic depth generalizes. Thanks to recent advances in the measurement of substantive democracy, we can now address these puzzles.

Accordingly, we gather hypotheses about substantive democratization in two parts. First, we use explanations of formal democratization to develop hypotheses about democratic depth. To formulate our expectations about democratic deepening, we assume here that substantive democratization is governed by the same dynamics as formal democratization. This is of course an assumption that we test in the analysis that follows, but it suffices for formulating our expectations $a$ priori.

Second, we use qualitative work on democratic depth as well as a few cross-national studies of formal democratization to summarize contrasting expectations about the role of mass protest during regime transitions. We separate this set of hypotheses from the first to amplify the contribution of this paper, which is to propose and then show that sustained unarmed mobilization during regime transitions yields democratic dividends for post-transition regimes. 


\subsection{Standard Accounts of Democratization}

Whence formal democracy? Standard accounts of the rise of democracy tie it to the rise of capitalism. The view from modernization theory is that capitalism catalyzes democracy because it raises standards of living, advances the division of labor and incubates a tolerant citizenry (Inglehart and Welzel 2005; Lipset 1959). This argument has been criticized by those who argue that democratization is contentious rather than conflict-free. This criticism was made first by an older, comparative-historical tradition which argued that democracy is the result of a new balance of class capacities that economic development introduces. The classic statement of this argument is Barrington Moore's (1966), but this tradition includes those who, unlike Moore, argue that it is specifically the rise of non-elite capacities that matter (Rueschemeyer et al. 1992). A related criticism has been made by recent work in economics and political science. These authors argue that it is not the size of the pie but conflict over its distribution that governs democratization (Acemoglu and Robinson 2005; Ansell 2014; Boix 2003). While these 'redistributivists' all agree that democracy is the result of conflict between the classes, they each formulate the problem differently. These different formulations yield divergent expectations about whether it is high, low, or middling levels of inequality that will catalyze democracy.

Note that all these views share the position that democracy is endogenous to the development and distribution of economic resources. They can thus be usefully contrasted to a different set of arguments, following Wejnert (2005), which maintains that many of the determinants of democratization are exogenous to the economy. The arguments in this tradition include the view that democracy diffuses across borders (Wejnert 2005), that colonialism shape democratization (Olsson 2009), that oil economies are less likely to democratize (Ross 2012), that only certain institutional settings can incubate democracy (Somers 1993), that a country's political history substantially governs its future prospects (Geddes, Wright, and Frantz 2014), or that countries with large ethnic minorities will find democratization harder.

\subsection{Elite-Led Transitions vs. Transitions from Below}

In what follows we test how well these hypotheses explain patterns of substantive democratization in the post-1950 world. But we pay particular attention to a different set of hypotheses borne of an adjacent debate. Scholars of democratization have also debated how a regime's origins shape its subsequent outcomes, with specific attention falling on the character of transitions. This debate is 
rooted in the observation that not all transitions are made equal. Some are contentious and involve mass mobilization; some are initiated by elites (Haggard and Kaufman 2016).

An earlier and influential literature held a pessimistic view about the consequences of protest. These scholars argued that mobilization might force a "pivotal elite" to abort the transition (O’Donnell and Schmitter 1986). Indeed, as Huntington (1984) argued, even if protest succeeded in installing democracy, the resulting regime was likely to be unstable. This negative view of popular mobilization had its lineage in Huntington's earlier work about stability and order in developing countries. Huntington (1968) had argued that in the absence of institutions to contain demands for participation, social mobilization might overload the political system. Similarly, in a report about the governability of democracy to the Trilateral Commission, he and his co-authors warned that the increasing participation of various groups in political activities had inhibited democracy, again by overloading the governing process and by fostering distrust in leadership (Crozier, Huntington, and Watanuki 1975). In this tradition, a recent study of democratic consolidation finds that cooperative transitions produce more durable and higher-quality democracies (Guo and Stradiotto 2016).

Yet several other recent studies dispute this pessimistic view. These authors argue that democracies emerging from episodes of popular mobilization are more durable (Bayer, Bethke, and Lambach 2016; Kadivar 2018) and that they score higher in measures of electoral and liberal progress(Bethke 2017; Bethke and Pinckney 2016a; Haggard and Kaufman 2016). Specifically, Bethke and Pinkcney (2016a) show that democracies that emerge from nonviolent campaigns have higherquality electoral institutions because they improve the freedom of expression. This literature, nonetheless, remains in the realm of formal democracy. One of the contributions of this paper is to transport the insights of this developing view to a new puzzle.

Why might movements spur post-transition democratization? Those who argue that they do have so far given two kinds of reasons. First, they have argued that mobilization matters because movement veterans enter the post-transition regime. Movements thus furnish new democracies with a pro-democratic leadership. Second, scholars have argued that movements matter because they enhance post-transition civil society. Civil societies with a history of mobilization will be that much more likely to mobilize after transition, and thus better placed to hold officials of post-transition regimes accountable (Bethke 2017; Haggard and Kaufman 2016; Kadivar 2018). 
In this paper, we seek to give the mechanisms by which movements matter a firmer foundation in the recent literature on how civil society shapes the state. Klein and Lee (Forthcoming) have recently identified three ways in which civil society can shape policy: first, by building parallel economic and political institutions for their own constituents ('the politics of substitution'); second, by influencing policies without entering policy-making institutions ('the politics of influence'); and third, by entering state institutions and reshaping them to their own ends ('the politics of occupation'). These three 'modes of civil society infiltration' comprise what they call the 'politics of forward infiltration'.

Here we argue that it is these three mechanisms that explain why longer pro-democracy movements result in deeper democracies. We corroborate this argument, later, in our case study of Brazil's paradigmatic transition.

First, movements build stronger civil society networks. When community organizing has been a part of the pre-transition mobilization, civil society is more organized, and activists more adept. This corresponds to the "politics of substitution": activists rely on non-state networks to avoid regimes' repressive measures. Why do these networks advance substantive democratization after a transition? First, internal practices of horizontalism and deliberative democracy provide a blueprint for activists to build participatory and deliberative institutions when they enter office. ${ }^{2}$ Second, when participatory institutions are in place, previous practices of internal democracy within civil society mean that collective actors are equipped with skills and capacities to participate in deliberative processes (Baiocchi et al. 2011), which in turn inoculates these institutions from paralysis and ineffectiveness.

Second, long movements produce an array of pro-democratic leaders. These movement veterans are embedded in pro-democratic political parties. Upon taking political and bureaucratic offices, they are well-placed to build institutions that empower disadvantaged groups. This is the "politics of occupation". Parties borne of years of struggle will be disposed to deliver to the masses that they mobilized.

Finally, movements are likely to generate a strong "politics of influence" after the transition. Activism begets activism. A well-organized civil society also empowers excluded groups to organize themselves, articulate their interests, and to win inclusion and redistribution (Baiocchi, Heller, and Silva 2008; Wampler and Avritzer 2004a). Furthermore, the past success of contention legitimizes

\footnotetext{
2 There is thus an important link between the politics of substitution and occupation. Klein and Lee do not note this in their piece, but we find that it was pivotal to democratic deepening in Brazil.
} 
contentious methods as a major means of claim-making (Fishman 2011). Movements do not always endure, after all, upon coming to power; they often betray their egalitarian ideals (Silva 2009). Under such conditions, contentious collective action supports social redistribution (Roberts 1998). Strong movements can hold ruling parties to their redistributive promises (Ekiert, Kubik, and Wenzel 2017; Silva 2009).

\section{Data and Methods}

Our major interest in this paper is to understand why formal democracies vary in the extent to which they empower their constituents. Our key hypothesis is that substantive democratization is in part driven by sustained, unarmed mobilization prior to transition, though we also evaluate other explanations in what follows.

We first approach this puzzle econometrically. We run panel regressions to assess determinants of substantive democratization in all countries that transitioned to democracy between 1950 and 2010. To define democratic periods, we followed Geddes et al (2014:6), who classify as democracies all political regimes whose executive comes to power through "direct, reasonably fair, competitive elections". These authors code the characteristics of different political regimes, providing extensive details about their coding. Table 6 in the Appendix lists details of all democratic regimes in our sample. ${ }^{3}$

\section{Substantive Democratization}

To measure substantive democracy we use the Varieties of Democracy dataset (V-Dem 8.0) (Coppedge et al. 2018; Pemstein et al. 2018). Unlike existing datasets, V-Dem measures democracy in multiple dimensions: electoral, liberal, participatory, deliberative, and egalitarian. The first two overlap with traditional indices of formal democratization, but the other three are new. Because they are the three ideals which recur in the literature on substantive democracy, they are our focus in what follows. Each index registers important changes on the road to deep democracy, Deliberative

\footnotetext{
${ }^{3}$ Not all democracies remain democratic. These countries leave our sample upon their reversion to authoritarianism, though they re-enter our sample in the event of another democratic transition.
} 
democracy is higher when political elites reach decisions via deliberation rather than appeals to solidary attachments or parochial concerns. Participatory democracy is higher when citizens are actively involved in the political process, through direct democracy and local bodies. And egalitarian democracy is higher when ordinary people face fewer barriers in exercising their formal liberties due to a more balanced distribution of resources and rights. See Table 1 for a summary of V-Dem's own definitions. ${ }^{4}$

\section{Contentious Mobilization}

We have argued that sustained unarmed mobilization prior to a democratic transition should advance substantive democratization. To measure the duration of antecedent mobilizations, we use a dataset measuring anti-authoritarian mobilizations (Kadivar 2018). Based on a wide array of secondary sources (see Appendix C for details), this dataset codes all contentious mobilizations prior to all post1950 transitions. Building on Chenoweth and Stephan's (2012) definition of a campaign and Tilly and Tarrow's (2007) definition of contentious politics, Kadivar (2018) defines contentious mobilization as collective action comprising at least 1,000 people making demands on a government.

The dataset measures sustained unarmed mobilization by the duration (in years) of consistent mobilization leading to the democratic period in question. This is the main independent variable in our analysis, but the dataset does also code the duration of armed mobilization preceding transition, which we include alongside. If no mass movement existed, then these variables are coded as zero. In total, there are 108 democracies in the dataset, since different democratic periods in the same country count as separate instances of democracy. Of these 108 democratic spells, 69 are in our final sample. ${ }^{5}$ 46 of these 69 democracies were preceded by unarmed mobilizations lasting at least a year.

Of course, it is plausible that the duration of pro-democratic mobilization is endogenous to the quality of the regime in which it appears. Perhaps the character of the authoritarian regime explains

\footnotetext{
${ }^{4}$ Each of the non-electoral dimensions has 'thin' and 'thick' variants. The 'thick' variants combine information about progress in these dimensions with the electoral democracy score. This is intended to capture the intuition that electoral progress is the sine qua non of democracy---no matter how considerable the progress a regime has made in other dimensions, it cannot be considered a democracy unless it holds free and competitive elections. We use the 'thin' variants in this analysis, since our objective is to gauge the determinants of distinctive progress in each of these dimensions.

5 This is a function of data availability. As shown in the Appendix, our results are robust to considering sparser specifications in which we are able to study patterns in many more countries over many more years.
} 
the coincidence of contentious movements and any substantive democratization we might observe. We account for this possibility by controlling for two observable characteristics of the antecedent dictatorship in the models described below. First, we add a measure of the old regime's aggregate civil society score (from the V-Dem dataset) in the year prior to the start of the pro-democratic campaign. This score is formed from a variety of questions posed to country experts about the autonomy, influence, and membership of civil society organizations. As an example: by our coding, the campaign to unseat Poland's communist regime began in 1980, so we include the V-Dem civil society score from 1979 as a measure of that regime's permissiveness towards civil society on the eve of the campaign to depose the dictatorship. Second, we add a measure of the old regime's average civil liberties score (also from V-Dem) over the life of the pro-democratic campaign. Again, in Poland, this campaign lasted between 1980 and 1989, so we include the civil liberties score from these years in all models.

\section{Standard Explanations}

While we hypothesize that sustained mobilization advances substantive democratization, nothing in our review of the literature suggests that it is the only cause. Since our paper is among the first to examine variation in substantive democratization within formally democratic regimes, we are interested in testing other explanations, too. How well do theories of formal democratization explain democratic deepening?

The foremost of these explanations is the view that economic modernization catalyzes democracy. To test this hypothesis, we measure all the channels by which modernization is believed to matter. We include measures of GDP per capita and its growth rate in all models, to assess whether economic development itself leads to democratic deepening. Some believe modernization matters because development yields a middle-class, which demands democracy. To test this channel specifically, we also include measures of the share of the population living in large cities (Banks and Wilson 2013) and the average level of education (Barro and Lee 2013).

As noted earlier, the redistributivist challenge to the modernization view is that it is not wealth but its distribution that governs democratization. We test this by including a measure of income inequality in all models (Solt 2016). The related, major criticism of the modernization view is that it misunderstands why development matters --- not because it yields a middle-class, but because it 
transforms the class capacities of ordinary people (who demand democracy) and landlords (who oppose it). To test this hypothesis, our models also include a measure of landlord power (Ansell and Samuels 2010), as well as a measure of the disruptive capacity of the working-age population (Usmani 2018). ${ }^{6}$

As mentioned earlier, we also test several 'exogenous' theories of democratization. To test whether past colonial legacies influence present-day democratization, we include dummies for the identity of a country's colonizer as well as the number of years that a country was colonized. To test the view that democratization is more difficult in oil-producing countries, we include a measure of oil production per capita (Ross 2012). To test the hypothesis that ethnic fractionalization makes institution-building more difficult, we include controls for both ethnic fractionalization and the size of excluded populations in a country (Wimmer, Cederman, and Min 2009). To establish how a country's regional neighbors and the international context bear on democratic deepening, we include the lag of the average value of the dependent variable across all other countries in the region and the share of a country's trade in GDP (World Bank 2012). Finally, to assess the importance of a country's institutional and political history, we include a variable that counts the number of years a country has been democratic before the democratic spell in question, and a set of dummies to measure the character of the antecedent authoritarian regime---whether personalistic, one-party or military.

\section{Methods}

To estimate the impact of these variables on subsequent democratic progress, we fit autoregressive distributed lag models (ADL's), so-called because we include a lag of the dependent variable on the right-hand side. This specification allows us to estimate both the short-run (i.e., immediate) and long-run (i.e., cumulative) effects of each independent variable on the outcome (De Boef and Keele 2008). Together with error-correction models, which are algebraically equivalent (ibid.), ADL's have become conventional for analysis of time-series cross-sectional data such as these. In what follows, for the purposes of parsimony, we focus entirely on the long-run effects (Table 5 in the Appendix presents the original short-run estimates). In addition, we include year fixed effects to account for time trends and shocks common to all countries, regional fixed effects to account for any

\footnotetext{
${ }^{6}$ Usmani (2018) measures disruptive capacity as the proportion of the working-age population employed in manufacturing, mining, construction, or transport.
} 
time-invariant, region-specific confounders, and we adjust our standard errors for clustering at the country level.

In our preferred models, we further add country-level random effects, to capture countryspecific heterogeneity not captured by the regional fixed effects or other variables. Given the constraints of our dataset, these are more appropriate than country-level fixed effects. While countrylevel fixed effects have inferential appeal (Firebaugh, Warner, and Massoglia 2013), they are better suited to a sample in which each country experiences several democratic transitions. This is very far from being the case in the post-1950 world. Over the life of our sample, most countries experience only a single democratic transition (46 of the 55), and thus only a single democratic spell. It is only in 7 countries in our sample that there is any variation in the length of antecedent campaigns. Moreover, a fixed-effects approach would greatly limit the variation being considered in our key independent variable. As Table 3 shows, the average in-sample standard deviation of this variable is about 2.6 years, but its average within-country standard deviation is only 0.12 years. In short: these are poor grounds for within-country inference. We expect much of the country-level heterogeneity to be accounted for by the country random effects, regional fixed effects and the history-specific dummies, but in robustness tests we discuss estimates from two supplementary models which include country-level fixed effects.

\section{Results}

Table 4 presents long-run estimates from our preferred specifications. We present three models, one for each of three main dependent variables in our analysis: deliberative democracy, participatory democracy, and egalitarian democracy.

\section{Contentious Mobilization}

Our main hypothesis finds strong support across the three models. All else equal, the duration of unarmed, contentious mobilization prior to transition is positively associated with subsequent 
substantive democratization. This is not true of armed mobilization, ${ }^{7}$ which suggests that it is not their contentiousness but specifically the mass, democratic character of unarmed campaigns that matters for democracy.

We report standardized estimates, for ease of interpretation. In the long-run, a hypothetical increase in the length of mobilization of roughly 2.6 years leads to discernible improvements in the level of democracy: 0.58 standard deviations in the deliberative dimension (95\% CI: 0.29 to 0.99), 0.41 standard deviations in the participatory dimension (95\% CI: 0.10 to 0.75 ), and 0.25 points in the egalitarian dimension (95\% CI: 0.11 to 0.41 ). In summary, all else equal, when authoritarian regimes are toppled by prolonged, unarmed movements, they are replaced by democracies which tend to become more deliberative, more participatory, and more egalitarian than those which were born amidst quiescence. ${ }^{8}$ As discussed in detail in the Appendix, these three estimates are robust to a wide array of robustness checks.

How large are these estimates? Had mobilization been more common, the post-1950 world would have been a more democratic place---but how much more democratic? To address these questions, we consider two counterfactuals which are distinguished by the size of the mobilizations involved. First, we estimate outcomes in a hypothetical world in which all transitions unfolded amidst quiescence; where there was no mobilization prior to any democratic transition in our sample. Second, we estimate outcomes in a world in which all transitions were detonated by mass mobilizations of 4.0 years (the 90th percentile value of all post-1950 mobilizations). In both cases, all other variables are held at their observed values. We loop through every regime and predict the level of each outcome under each scenario. Rather than discussing trends in an idiosyncratic country, we focus here on aggregate trends across all regimes. To do this, we order these predictions by the number of years elapsed since the transition. Moreover, since the level of any given dependent variable has no intuitive

\footnotetext{
${ }^{7}$ In fact, the estimated effect of armed mobilization is negative, though not statistically significant in our preferred (or most other) specifications.

8 The V-Dem dataset also includes two continuous measures of the formal dimensions of democracy: one electoral, and one liberal. One can use these data to pose a parallel question: does unarmed mobilization predict the extent of progress that formal democracies make towards competitive, free elections and towards securing individual liberties? This is not our focus in this paper, but in line with other work (Bethke and Pinckney 2016b; Kadivar 2018), we find that the number of years of unarmed mobilization is a statistically significant predictor of formal democratization as well. In other words, democracies borne of contention tend to become more electorally competitive and to better safeguard individual rights than democracies borne of quiescence. Specifically, in the long-run, a counterfactual increase in the length of mobilization of 2.5 years is associated with a 0.40 standard deviation increase in the electoral dimension (95\% CI: 0.08 to 0.69 ) and a 0.27 point increase in the liberal dimension (95\% CI: 0.0 to 0.65 ). (This last estimate is only statistically significant at alpha $=0.10$, but the underlying short-run estimate is significant at alpha $=0.05$, and in a sparser specification which includes more countries and years the long-run estimate is statistically significant at alpha=0.01.)
} 
meaning, here we discuss progress rather than the predicted levels. In other words, for each democratic period, we calculate the gains made under each counterfactual (i.e. the predicted democracy score in a given year in a given period minus the actual democracy score on the eve of transition leading to that period). Section B of the Appendix gives details.

The counterfactual impact of large mobilizations is best captured by the difference in gains made under the two scenarios---by the additional progress made in a world filled with mass mobilization as compared to a world of generalized quiescence. Figure 1 plots the magnitude of these additional gains, as a function of the number of years that have elapsed since transition. Gains due to mobilization are sizeable in all dimensions. Had all post-1950 democracies in our sample been preceded by 4.0 years of unarmed mobilization, they would have been significantly more democratic than in a universe in which the masses had never mobilized. Ten years out from transition, average additional gains amount to 0.86 standard deviations in the deliberative dimension (95\% CI: 0.51 to 1.23 ), 0.54 standard deviations in the participatory dimension (95\% CI: 0.18 to 0.91 ), and 0.34 standard deviations in the egalitarian dimension (95\% CI: 0.17 to 0.48$)$. In short: a quiescent world would have been substantially less democratic, and a mobilized world substantially more.

\section{Other Explanations}

Granted, the fact that unarmed mobilization is a significant predictor of substantive democratization does not imply that it is its only explanation. We find that other features of a democracy's economic, political, and institutional history also help explain the observed variance in levels of substantive democracy. Since it is the puzzle of these patterns that animates this paper, we here review these results. Space constraints do not allow us to explore these findings in any detail, but the results anchor our view that there is still much more to be learned about substantive democratization. We first consider standard explanations for democratization that identify factors endogenous to development and its distribution, before turning to the exogenous accounts.

We find little evidence for the modernization view that economic development or any of its correlates detonate democracy. Neither GDP per capita, its growth rate nor levels of urbanization are obviously associated with levels of substantive democracy. (The one exception is in the participatory dimension, where higher growth is associated with lower democracy at alpha=0.10.) Moreover, in our sample, higher levels of education are associated with less progress in the deliberative and participatory 
dimensions. If it is right to interpret average levels of education as an index of middle-class growth, this may reflect the fact that a growing middle-class has incentives to lock the poor out of the political process.

If not modernization, what about the challenge to that modernization view that democratization is a contentious process? We do find that more unequal democracies are substantively less democratic in the deliberative and egalitarian dimensions. This aligns with Boix's older formulation of the puzzle, according to which lower levels of inequality make elites more willing to concede democracy to the poor (Boix 2003). It does not support the more recent argument made by Ansell and Samuels (2014) that higher levels of inequality should incubate democracy. Separately, we also find support for the class-centric account that stronger landlords hamper democracy while ordinary people advance it (Rueschemeyer et al. 1992; Usmani 2018). Landlord power is negatively associated with substantive democracy in the participatory and egalitarian dimensions, while disruptive capacity is positively associated with democracy in the deliberative and participatory dimensions.

What about those arguments which focus on factors exogenous to capitalist development? First, and surprisingly, we find that oil production per capita is positively associated with levels of substantive democracy in all three dimensions. This relationship survives several robustness tests. It is not obviously driven by patterns in outlying countries. Even in specifications in which we omit the biggest (Venezuela) or even the biggest three (Mexico, Ecuador additionally) oil producers, oil production per capita is positively associated with participatory and egalitarian democracy. Similarly, the result survives the addition of country fixed-effects (and extension of the sample to include all countries), as well as a sparser model which drops all variables testing other hypotheses. Finally, it is not just positively associated with democracy in these three substantive dimensions, but also with levels of electoral and liberal democracy (see Appendix). Previous work on the oil-democracy relationship has argued that oil hinders formal democracy (Ross 2012). What explains the discrepancy? Our suspicion is that it is explained by our choice of dependent variable. When we follow Ross and run our models on the Polity2 score, we find the expected negative association. Given that the Varieties of Democracy dataset represents a substantial improvement over the Polity2 score, this is surely a profitable area for future research.

Second, we find that larger democracies are less substantively democratic. This is the only other variable (alongside unarmed mobilization and oil production) which is a statistically significant predictor of all three dimensions of substantive democracy. Past work has not paid much attention to 
population size as inhibiting democracy, but it bears noting. We suspect this is explained by the difficulty of coordinating political institutions and perhaps also collective action in larger societies, though establishing these mechanisms will require more evidence than we are able to gather in this paper.

Otherwise, no other variables are consistently significant across multiple dimensions. We find evidence of regional diffusion, but only in the egalitarian dimension. Higher levels of trade are positively associated with levels of deliberative democracy only. Democracies that were colonized longer have lower levels of participatory democracy, which is at odds with the findings in Olsson (2009). Countries that have a longer history of democracy or which emerge from rule by a single party exhibit higher levels of deliberative democracy. Finally, in line with Wimmer et al (2009), we find that countries with a larger excluded population exhibit lower levels of participatory democracy.

\section{Case Study: The Long March to Democracy in Brazil}

The evidence above sheds light on substantive democratization in the post-war world. However, it is not well-suited to establishing the mechanisms underlying the various associations we have documented thus far. Here we seek to elaborate the mechanisms that link our key independent variable to subsequent substantive democratization. We do this by analyzing a paradigmatic case: Brazil. Brazil is illustrative because it experienced both a lengthy period of contentious mobilization under authoritarianism and a remarkable deepening of its democracy after the transition to formal democracy.

We draw on the 'politics of forward infiltration' identified by Klein and Lee (Forthcoming) to explain democratic deepening in Brazil: substitution, occupation, and influence. In the Brazilian case, as we argue below, all three of these mechanisms are in evidence in the democratic period. And in fact, based on the case study below, we propose a slight extension of Klein and Lee's framework to consider an interaction between the politics of substitution and the politics of occupation. Substitution is important for producing autonomous spaces for movements to model alternative, democratic practices. As these movements later begin to occupy the state, they fuse the practices developed in the substitutive mode into formal institutions, thereby deepening their democratic character. 


\section{Contentious Mobilization Under Authoritarianism}

A long line of social scientists have shown that contentious mobilizations were decisive to the Brazilian transition (Keck 1995; Seidman 1994). As early as the mid-1970s, a broad front had emerged to demand elections. This constellation of movements linked together independent trade unions, neighborhood groups, an urban reform movement, Catholic churches, and cultural groups. Such "social movement unionism" integrated demands for substantive democracy with calls for liberal and electoral reforms. Labor agitation gained force in 1977 and strikes in the industrial suburbs of São Paulo in the 1978 and 1979 made clear that these social movements could challenge the authority of the military dictatorship.

The most significant political party to emerge out of this period of struggle was the Worker's Party (PT). The PT's importance lay in its capacity to articulate social movement demands in the political sphere. The party first participated in tightly-controlled parliamentary elections in 1982. After a poor showing, the party returned to its base in trade unions and social movements. While this initially seemed like a retreat, it is precisely this process of organizational renewal that explains the steady growth of the PT in later periods (Keck 1995).

In 1984, the "Diretas Já" movement for direct elections united this social movement-trade unionist alliance with more middle-class segments. These protests led to indirect presidential elections in 1985, the constitution of 1988 and the first direct elections of 1989. The sequencing of this transition opened avenues for expressing voice and building capacities in civil society. The participation of the PT in constitutional negotiations opened space for social movements to gain standing in the negotiations (Kingstone and Power 2008). Primarily, civil society associations influenced these negotiations by proposing popular amendments (Whitaker 1994). Key chapters on health, social assistance, and urban politics were all altered after such amendments (Avritzer 2012). The new constitution of 1988 ultimately carried some of the most significant socio-economic protections of any constitution in the world. This opened the possibility for deepening democracy in the years to come. 


\section{Democracy}

The alliance of activist movements and party organizations which came together in the pro-democracy struggle was decisive in consolidating formal democracy once established. This is well documented in the literature. In this section, instead, we focus on the mechanisms that link the contentious mobilization that occurred under Brazil's authoritarian regime to the deepening of Brazil's democracy. What were these mechanisms? We note three. First, social movements had built autonomous spaces, free of the influence of authoritarian institutions. After the transition, these were progressively incorporated into formal governing institutions, first into municipal and then federal structures. This fusion of the politics of substitution to the politics of occupation deepened the participatory and deliberative dimensions of democracy. Second, movement activists that had taken office ensured that the Brazilian state was responsive to popular demands. In particular, this strengthened the egalitarian dimensions of democracy. Finally, civil society in the democratic era continued to renew itself, surfacing new organizations that anchored an enduring politics of influence.

\section{From the politics of substitution to the politics of occupation}

The ecosystem of social movements that birthed the PT during the authoritarian period had constructed powerful forms of autonomous organization. These included practices such as land occupations and self-help home construction. When amplified by the politics of occupation in the democratic era, these practices profoundly transformed Brazilian democracy.

How did this unfold? In the participatory and deliberative dimensions, the legacy of the politics of substitution were pivotal to subsequent deepening. After all, Brazilian democracy was remarkable for the extent to which the new PT regime established participatory institutions at the local level, undermining long-existing clientelist modes of governance (Hagopian 1996). Though the constitution of 1988 provided a legal framework for these councils, in and of itself this meant little. Research has documented instances where horizontalism has led to paralysis or ineffectiveness (Fish 1995; Freeman 1972). This was not the case in Brazil precisely because practices of participation and deliberation were already common to trade unions and social movements. The prior politics of substitution practiced by social movements in non-state spaces formed collective actors with the capacities to occupy these spaces. Movements were prepared with an understanding of public institutions and the ability to speak. And thus, these institutions delivered to the PT's working-class base without alienating the middle classes who also participated in the councils. Participatory and sectoral budgeting councils were a 
common attribute of PT-run cities as soon as they began to take over mayoral seats in direct elections in 1989 (Wampler and Avritzer 2004b). Though these councils have exhibited some variation in the quality of participation and influence on policy, they are more effective at building citizenship than comparable institutions in other countries (Houtzager and Acharya 2011). Furthermore, the emergence of these participatory institutions incubated civil society associations in the cities where they were instituted (Baiocchi et al. 2008).

The legacy of the substitutive mode was felt not just in the participatory and deliberative dimensions. In cities such as São Paulo and Porto Alegre, following the wave of PT mayors in the first direct elections of 1989, local governments began supporting housing movements involved in land occupations to begin "self-construction" housing projects and to formalize previously informal "favela" settlements. These projects had first begun in the peripheries of Brazil's largest cities during the military dictatorship. Under authoritarian control, new housing movements used these projects to organize residents and initiate a culture of rights-claiming (Holston 2009). Under a democratic regime, armed with the power of the state, these projects delivered key public goods to poor citizens. Local control, increased bureaucratic capacity, the empowerment of social movements, and improved distribution of public services went together.

\section{Consolidating the politics of occupation}

The 2002 national election proved a watershed for the further development of the egalitarian dimensions of Brazilian democracy. The PT implemented redistributive policies in labor, healthcare, land and housing. These were not only responsive to movement demands, but often implemented through the occupation of key government offices by movement leaders. In this way, this era heralded a significant expansion of egalitarian democracy.

The link between the PT's movement roots and these new policies was clear. One of the main contributors to a reduction in inequality was the regular rise in the minimum wage (Ban 2013), which responded to the PT's origins in the labor movement. The provision of universal health care was a hallmark program of the PT government, which responded to a strong movement of health professionals known as the sanitaristas (Gibson 2019). The new Unified Health System was often staffed by sanitaristas and led to gains in life expectancy and drops in infant and maternal mortality (Gagnolati et al. 2013). The scaling up of the cash transfer program of Bolsa Escola, begun in the municipality of Belo Horizonte, to the national Bolsa Familia program is perhaps the most well-known 
instance of policy under the PT-controlled presidency (Sugiyama 2008). The link between redistribution and the move from clientelistic to programmatic welfare policies is most clearly exemplified by the administration of Bolsa Familia. Federal transfers went to beneficiaries, and not through local political bosses. Sugiyama and Hunter (2013) have cited this aspect of the program as a watershed in breaking the hold of clientelism.

The urban reform movement achieved a major victory around the same time with the passage of new laws, such as the City Statute in 2001. This legislation was designed to realize some of the key "aspirational" socio-economic rights recognized by the 1988 constitution. These legal and bureaucratic shifts were signals of federal government support for decentralized management of public goods provision (Fernandes 2007). The Ministry of Cities that was brought into existence under the PT in 2003 included high ranking staff positions for professionals associated with the urban reform movement. Furthermore, the PT pushed investments in public infrastructure through the Growth and Acceleration Program (PAC) in 2007 and in low-income housing through the My House My Life (MCMV) program in 2009 (Pires and Gomide 2016).

\section{The politics of influence}

Like many poor and middle income countries, policy space in Brazil is constrained by the whims of the global economy (Rudra 2002). But strong social movements exercised their influence to push for new reforms. The PT was pressured by its base to pursue egalitarian reforms (Lee 2016).

Movements continued to shape the political agenda well into Brazil's democratic period. ${ }^{9}$ The social movements that had organized for a democratic transition faced a dilemma in the post-transition

\footnotetext{
9 To be clear, our paper relies on this case study of Brazil to establish the mechanisms that link mobilization to deepening democracy. It is beyond the scope of our paper to do this in detail for all mechanisms and all cases. We note here that other paradigmatic cases also suggest that pro-democracy movements yield vibrant civil societies that exercise the politics of influence post-transition. In South Africa union density increased after the transition (Marais 2001), and the rate of protest activities stayed the same (Klandermans 2015). In Argentina, human rights groups that emerged under the military dictatorship continued operating in the new democracy (Levitsky 2005). In Poland, Solidarity remained one of the two big labor unions in the country, played an important role in consolidation of democracy. And other forms of civil society organizations also grew after the transition (Ekiert and Kubik 1999; Ekiert, Kubik, and Wenzel 2017). This last observation is challenged by Grodsky (2012), who argues, in fact, that the occupation of state office weakened the pro-democracy movement in Poland. But his argument has two major weaknesses. First, Grodsky (2012) relies mostly on interviews with veterans of the pro-democracy movement to substantiate his claims. These may not be the most reliable metric. Studies that rely on more dispassionate sources of data (such as surveys about participation in protest or registries of NGOs) come to different conclusions (Ekiert et al. 2017). Second, Grodsky's assessment of civil society's strength in these countries does not pose the right counterfactual for our argument. Grodsky (2012) claims Polish civil society was weaker after Solidarity leaders took government positions in 1989. Here, his counterfactual is that civil society would have been stronger had Solidarity continued as a movement, while other politicians with democratic convictions had led the country. But this is not the counterfactual we consider in this paper. In arguing that stronger
} 
period. Rural land reform efforts — advocated by the Landless People's Movement (MST) — were formalized after many land occupations (Ondetti 2006). Urban reform movements achieved federal legislation in the form of the city statute and a ministry at which they could direct grievances (Fernandes 2007). Inevitably, challenges emerged. And yet, the coordination across local and national scales that had been so integral to the movements' successes made them remarkably resilient. Democratic consolidation also saw some existing movements rise to more significant prominence in the democratic era. In particular, movements for the rights of Afro-Brazilians, indigenous people, and LGBTQ, have deepened demands for egalitarian inclusion and representation (Paschel 2016).

\section{Conclusion}

Why do some new democracies deepen while others stagnate? Some regimes promote the participation of citizens and ensure equal access to the decision-making process. Others, however, remain democracies in procedure only. In this paper we derived hypotheses about substantive democratization from theories of formal democratization and the scholarship on democratic deepening. We exploited a new dataset which measures substantive dimensions of democracy participatory, deliberative, and egalitarian. Previous cross-national studies of democratization have focused on the quality of electoral and liberal democracy (Boix 2011; Geddes et al. 2014; Jaggers and Gurr 1995), but here we presented the first comprehensive cross-national analysis of democratic deepening.

What did we find? In general, our analysis suggests that substantive democratization is a contentious process. We found that one of the most consistent and powerful predictors of democratic deepening is the length of contentious mobilization prior to democratization. We further found partial support for inequality- and class-based explanations of democratization, both of which propose that democratization is conflict-filled rather than conflict-free, and no support for the modernizationbased account they criticize. Granted, this is not to argue that democratization is driven solely by contention between key actors. As discussed, the level of oil production and the size of a country's population were also consistent predictors of democratization across dimensions. The first of these findings, in particular, invites further research. We also found support for other hypotheses, though

movements yield stronger civil societies, our implicit counterfactual is to a Poland in which Solidarity had never emerged. We thank a reviewer for pushing us on this point. 
none were as consistent as these major findings. Nonetheless, all things considered, we believe that our evidence re-issues the argument made by McAdam, Tarrow, and Tilly (2001): that because social movements, revolutions and democratization share similar contentious mechanisms, they belong together in the field of contentious politics.

To theorize the mechanisms that link contentious mobilization to substantive democratization, we drew on recent work on civil society and the state to argue that movements advance substantive democracy in three ways (Klein and Lee Forthcoming). First, they engage citizens in self-organizing, which provides a model and foundation for the deepening of democratic institutions (the politics of substitution). Second, they produce a political elite with the commitments to make government institutions participatory, deliberative, and redistributive (the politics of occupation). Third, they embolden civil society to make demands for inclusion after transition (the politics of influence).

We argued that the case of democratization in Brazil illustrates these mechanisms. Brazil owes its deeper democracy to a programmatic, redistributive political party, and an ecosystem of trade unions and social movements forged through lengthy contentious mobilization under authoritarianism. The interaction between party, movement, and state institutions in the democratic period expanded democracy not only along liberal and electoral dimensions, but in participatory, deliberative, and egalitarian dimensions as well. Our paper illustrated the mechanisms of substitution, occupation, and influence, and extended Klein and Lee's original formulation to show the positive effects on democratic deepening when the politics of substitution evolve into the politics of occupation.

In recent months, of course, there has been a resurgence of right-wing authoritarianism in Brazil. Has contentious democratization backfired? In our view, the lesson of recent years is exactly the opposite. In fact, it is subaltern demobilization that has paved the way for the new right-wing. Recent literature suggests that, as the role of independent unions and other social movements receded, a personalistic "Lulismo" emerged (Singer 2018). This made the PT's project brittle. Moreover, Brazilian democracy has been buffeted by authoritarian developments beyond its borders. The wave of financial crises that began in the United States in 2008 and then in Europe have helped push large, middleincome countries with liberalized economies in an authoritarian direction (Bradlow 2018). Despite these developments, the duration and depth of democracy in Brazil today is noteworthy. In a weaker democracy, the emergence of an aspirant strongman like Jair Bolsonaro would surely sound its death 
knell. If anything, Brazil's experiences of contentious mobilization leaves its citizens well-placed to repel Bolsonaro's challenge.

The long march to democracy is full of conflict. In an increasingly global age of challenges to democracy, we dare not avoid it. 


\section{Bibliography}

Acemoglu, Daren and James A. Robinson. 2005. Economic Origins of Dictatorship and Democracy. Cambridge University Press.

Ansell, Ben and David Samuels. 2010. "Inequality and Democratization: A Contractarian Approach.” Comparative Political Studies 43(12):1543-74.

Ansell, Ben W. 2014. Inequality and Democratization: An Elite-Competition Approach. New York, NY: Cambridge University Press.

Avritzer, Leonardo. 2012. "The Different Designs of Public Participation in Brazil: Deliberation, Power Sharing and Public Ratification.” Critical Policy Studies 6(2):113-27.

Baiocchi, Gianpaolo. 2003. "Emergent Public Spheres: Talking Politics in Participatory Governance." American Sociological Review 68(1):52-74.

Baiocchi, Gianpaolo, Patrick Heller, and Marcelo Silva. 2011. Bootstrapping Democracy: Transforming Local Governance and Civil Society in Brazil. Stanford, California: Stanford University Press.

Baiocchi, Gianpaolo, Patrick Heller, and Marcelo Kunrath Silva. 2008. "Making Space for Civil Society: Institutional Reforms and Local Democracy in Brazil.” Social Forces 86(3):911-36.

Ban, Cornel. 2013. "Brazil's Liberal Neo-Developmentalism: New Paradigm or Edited Orthodoxy?” Review of International Political Economy 20(2):298-331.

Banks, Arthur S. and Kenneth A. Wilson. 2013. Cross-National Time-Series Data Archive. Jerusalem, Israel: Databanks International.

Barber, Benjamin. 2004. Strong Democracy: Participatory Politics for a New Age. 20 Anv edition. Berkeley: University of California Press.

Barro, Robert J. and Jong Wha Lee. 2013. “A New Data Set of Educational Attainment in the World, 1950-2010.” Journal of Development Economics 104:184-198.

Bayer, Markus, Felix S. Bethke, and Daniel Lambach. 2016. “The Democratic Dividend of Nonviolent Resistance.” Journal of Peace Research 53(6):758-71.

Bethke, Felix S. 2017. "Nonviolent Resistance and Peaceful Turnover of Power." Peace Economics, Peace Science, and Public Policy 23(4):1-5.

Bethke, Felix S. and Jonathan Pinckney. 2016a. "Nonviolent Resistance and the Quality of Democracy." THE VARIETIES OF DEMOCRACY INSTITUTE.

Bethke, Felix S. and Jonathan Pinckney. 2016b. "Nonviolent Resistance and the Quality of Democracy." THE VARIETIES OF DEMOCRACY INSTITUTE.

Boix, Carles. 2003. Democracy and Redistribution. Cambridge University Press. 
Boix, Carles. 2011. "Democracy, Development, and the International System." American Political Science Review 105(4):809-28.

Bradlow, Benjamin H. 2018. "Trickle-Down Authoritarianism.” Boston Review. Retrieved January 29, 2019 (http:/ / bostonreview.net/politics/benjamin-h-bradlow-trickle-down-authoritarianism).

Coppedge, Michael, John Gerring, Carl Henrik Knutsen, Staffan II Lindberg, Svend-Erik Skaaning, Jan Teorell, David Altman, Michael Bernhard, M. Steven Fish, and Agnes Cornell, Sirianne Dahlum, Haakon Gjerløw, Adam Glynn, Allen Hicken, Joshua Krusell, Anna Lührmann, Kyle L. Marquardt, Kelly McMann, Valeriya Mechkova, Juraj Medzihorsky, Moa Olin, Pamela Paxton, Daniel Pemstein, Josefine Pernes, Johannes von Römer, Brigitte Seim, Rachel Sigman, Jeffrey Staton, Natalia Stepanova, Aksel Sundström, Eitan Tzelgov, Yi-ting Wang, Tore Wig, Steven Wilson, and Daniel Ziblatt. 2018. "V-Dem Dataset V8." Varieties of Democracy (V-Dem) Project. https://doi.org/10.23696/vdemcy18

Crozier, Michel, Samuel P. Huntington, and Joji Watanuki. 1975. The Crisis of Democracy: Report on the Governability of Democracies to the Trilateral Commission. New York: New York University Press.

Dahl, Robert A. 1972. Polyarchy: Participation and Opposition. New Haven u.a.: Yale University Press.

Dahl, Robert A. 2006. On Political Equality. 1 edition. Yale University Press.

De Boef, Suzanna and Luke Keele. 2008. "Taking Time Seriously." American Journal of Political Science 52(1):184-200.

Ekiert, Grzegorz and Jan Kubik. 1999. Rebellious Civil Society Popular Protest and Democratic Consolidation in Poland, 1989-1993. Ann Arbor: The University of Michigan Press.

Ekiert, Grzegorz, Jan Kubik, and Michal Wenzel. 2017. "Civil Society and Three Dimensions of Inequality in Post-1989 Poland.” Comparative Politics 49(3):331-50.

Fernandes, E. 2007. “Constructing the 'Right To the City’ in Brazil.” Social \& Legal Studies 16(2):201-19.

Firebaugh, Glenn, Cody Warner, and Michael Massoglia. 2013. "Fixed Effects, Random Effects, and Hybrid Models for Causal Analysis.” Pp. 113-32 in Handbook of Causal Analysis for Social Research, Handbooks of Sociology and Social Research, edited by S. L. Morgan. Springer Netherlands.

Fish, M. Steven. 1995. Democracy from Scratch: Opposition and Regime in the New Russian Revolution. Princeton, N.J.: Princeton University Press.

Fishman, Robert M. 2011. "Democratic Practice after the Revolution: The Case of Portugal and Beyond.” Politics \& Society 39(2):233-67.

Fishman, Robert M. 2016. "Rethinking Dimensions of Democracy for Empirical Analysis: Authenticity, Quality, Depth, and Consolidation." Annual Review of Political Science 19(1):289_ 309. 
Freeman, Jo. 1972. “The Tyranny of Structurelessness.” Berkeley Journal of Sociology 151-164.

Fung, Archon and Erik Olin Wright. 2003. Deepening Democracy: Institutional Innovations in Empowered Participatory Governance. Vol. 4. Verso Books.

Geddes, Barbara, Joseph Wright, and Erica Frantz. 2014. "Autocratic Breakdown and Regime Transitions: A New Data Set.” Perspectives on Politics 12:313-31.

Gibson, Christopher L. 2019. Movement-Driven Development: The Politics of Health and Democracy in Brazil. 1 edition. Stanford, California: Stanford University Press.

Gragnolati, Michele, Magnus Lindelow, and Bernard Couttolenc. 2013. Twenty Years of Health System Reform in Brazil: An Assessment of the Sistema Único de Saúde. The World Bank.

Grodsky, Brian K. 2012. Social Movements and the New State: The Fate of pro-Democracy Organizations When Democracy Is Won.

Guo, Sujian and Gary A. Stradiotto. 2016. Democratic Transitions: Modes and Outcomes. 1 edition. Place of publication not identified: Routledge.

Gutmann, Amy and Dennis Thompson. 2004. Why Deliberative Democracy? Princeton, N.J: Princeton University Press.

Haggard, Stephan and Robert R. Kaufman. 2016. Dictators and Democrats: Masses, Elites, and Regime Change. Princeton University Press.

Hagopian, Frances. 1996. Traditional Politics and Regime Change in Brazil. New York, NY: Cambridge University Press.

Heller, Patrick. 2000. “Degrees of Democracy: Some Comparative Lessons from India.” World Politics 52(4):484-519.

Holston, James. 2009. Insurgent Citizenship: Disjunctions of Democracy and Modernity in Brazil. Princeton, N.J: Princeton University Press.

Houtzager, Peter P. and Arnab K. Acharya. 2011. "Associations, Active Citizenship, and the Quality of Democracy in Brazil and Mexico." Theory and Society 40(1):1-36.

Huntington, Samuel P. 1968. Political Order in Changing Societies. Yale Univeristy Press.

Huntington, Samuel P. 1984. "Will More Countries Become Democratic?" Political Science Quarterly 99(2):193-218.

Inglehart, Ronald and Christian Welzel. 2005. Modernization, Cultural Change, and Democracy: The Human Development Sequence. Cambridge University Press.

Jaggers, Keith and Ted Robert Gurr. 1995. “Tracking Democracy's Third Wave with the Polity III Data." Journal of Peace Research 32(4):469-482. 
Kadivar, Mohammad Ali. 2018. "Mass Mobilization and the Durability of New Democracies." American Sociological Review 83(2):390-417.

Keck, Margaret E. 1995. The Workers`Party and Democratization in Brazil. New Haven, CT: Yale University Press.

Kingstone, Peter and Power, Timothy. 2008. "Introduction." in Democratic Brazil Revisited. Pittsburgh, PA: University of Pittsburgh.

Klandermans, Bert. 2015. "Movement Politics and Party Politics in Times of Democratic Transition: South Africa, 1994-2000.” Pp. 241-58 in Movements in Times of Democratic Transition, edited by B. Klandermans and C. van Stralen. Philadelphia: Temple University Press.

Klein, Steven and Cheol-Sung Lee. Forthcoming. "The Politics of Forward and Backward Infiltration: Towards a Dynamic Theory of Civil Society.” Sociological Theory.

Lee, Cheol-Sung. 2016. When Solidarity Works: Labor-Civic Networks and Welfare States in the Market Reform Era. New York, NY: Cambridge University Press.

Levitsky, Steven. 2005. “Argentina: Democratic Survival amidst Economic Failure.” Pp. 63-89 in Third Wave of Democratization in Latin America advances and Settbacks, edited by F. Hagopian and S. P. Mainwaring. New York: Cambridge University Press.

Lipset, Seymour Martin. 1959. "Democracy and Working-Class Authoritarianism." American Sociological Review 482-501.

Marais, Hein. 2001. South Africa: Limits To Change: The Political Economy of Transition. Palgrave Macmillan.

McAdam, Doug, Sidney G. Tarrow, and Charles Tilly. 2001. Dynamics of Contention. Cambridge ; New York: Cambridge University Press.

Moore, B. 1966. Social Origins of Dictatorship and Democracy: Lord and Peasant in the Making of the Modern World. Vol. 268. Beacon Press.

O’Donnell, Guillermo and Philippe C. Schmitter. 1986. Transitions from Authoritarian Rule, Vol. 4: Tentative Conclusions about Uncertain Democracies. Maryland, MD: The Johns Hopkins University Press.

Olsson, Ola. 2009. "On the Democratic Legacy of Colonialism.” Journal of Comparative Economics 37(4):534-551.

Ondetti, Gabriel. 2006. "Repression, Opportunity, and Protest: Explaining the Takeoff of Brazil's Landless Movement." Latin American Politics and Society 48(2):61-94.

Paschel, Tiana. 2016. Becoming Black Political Subjects: Movements and Ethno-Racial Rights in Colombia and Brazil. Princeton, N.J: Princeton University Press. 
Pemstein, Daniel, Kyle L. Marquardt, Eitan Tzelgov, Yi-ting Wang, Joshua Krusell, and Farhad Miri. 2018. "The V-Dem Measurement Model: Latent Variable Analysis for Cross-National and Cross-Temporal Expert-Coded Data." University of Gothenburg, Varieties of Democracy Institute: Working Paper No. 21, 3d edition.

Pires, Roberto Rocha Coelho and Alexandre de Ávila Gomide. 2016. "Governança e Capacidades Estatais: Uma Análise Comparativa de Programas Federais." Revista de Sociologia e Política 24(58):121-43.

Roberts, Kenneth. 1998. Deepening Democracy?: The Modern Left and Social Movements in Chile and Peru. 1 edition. Stanford, Calif: Stanford University Press.

Ross, Michael L. 2012. The Oil Curse: How Petroleum Wealth Shapes the Development of Nations. Princeton University Press.

Rudra, Nita. 2002. "Globalization and the Decline of the Welfare State in Less-Developed Countries." International Organization 56(2):411-45.

Rueschemeyer, Dietrich, Evelyne Huber Stephens, and John D. Stephens. 1992. Capitalist Development and Democracy. 1 st ed. University Of Chicago Press.

Seidman, Gay W. 1994. Manufacturing Militance: Workers' Movements in Brazil and South Africa, 19701985. Berkeley: University of California Press.

Silva, Eduardo. 2009. Challenging Neoliberalism in Latin America. Cambridge ; New York: Cambridge University Press.

Singer, Andre. 2018. O Lulismo Em Crise (Em Portugues Do Brasil). Sao Paolo, Brazil: Companhia das Letras.

Solt, Frederick. 2016. “The Standardized World Income Inequality Database*.” Social Science Quarterly 97(5):1267-81.

Somers, Margaret R. 1993. "Citizenship and the Place of the Public Sphere: Law, Community, and Political Culture in the Transition to Democracy." American Sociological Review 587-620.

Sugiyama, Natasha Borges. 2008. "Theories of Policy Diffusion: Social Sector Reform in Brazil." Comparative Political Studies 41(2):193-216.

Sugiyama, Natasha Borges and Wendy Hunter. 2013. "Whither Clientelism? Good Governance and Brazil’s Bolsa Família Program.” Comparative Politics 46(1):43-62.

Tilly, Charles and Sidney G. Tarrow. 2007. Contentious Politics. Vol. 10. Paradigm Publishers Boulder, $\mathrm{CO}$.

Usmani, Adaner. 2018. “Democracy and Class Struggle.” American Journal of Sociology 124(3):664-704.

Wampler, Brian and Leonardo Avritzer. 2004a. "Participatory Publics: Civil Society and New Institutions in Democratic Brazil.” Comparative Politics 36(3):291-312. 
Wampler, Brian and Leonardo Avritzer. 2004b. "Participatory Publics: Civil Society and New Institutions in Democratic Brazil." Comparative Politics 36(3):291-312.

Wejnert, Barbara. 2005. "Diffusion, Development, and Democracy, 1800-1999." American Sociological Review 70(1):53-81.

Whitaker, Francisco. 1994. Cidadão Constituinte: A Saga Das Emendas Populares. Rio de Janeiro: Paz e Terra.

Wimmer, Andreas, Lars-Erik Cederman, and Brian Min. 2009. "Ethnic Politics and Armed Conflict: A Configurational Analysis of a New Global Data Set." American Sociological Review 74(2):31637.

World Bank. 2012. World Development Indicators 2012. Washington, D.C.: World Bank. 
Table 1: Main Outcomes as Defined by V-Dem

\begin{tabular}{|l|l|l|}
\hline Variable & V-Dem Name & Definition \\
\hline Dimension & v2xdl_delib & $\begin{array}{l}\text { The deliberative component is higher when decisions are } \\
\text { judgetd to be reached via deliberation characterized by a } \\
\text { commitment to the common good, and not by emotional } \\
\text { appeals, solidary attachments, parochialism, or coercion. } \\
\text { V-Dem measures the extent to which political elites justify } \\
\text { their behavior by adverting to the public good, respecting } \\
\text { counter-arguments, and the extent to which they consult } \\
\text { other elites. }\end{array}$ \\
\hline Participatory & v2x_partip & $\begin{array}{l}\text { The participatory component is higher in countries which } \\
\text { actively involve citizens in the political process. It mea- } \\
\text { sures the extent to which citizens have direct influence } \\
\text { on policy decisions, through civil society, through direct } \\
\text { democratic initiatives, and through subnational bodies. }\end{array}$ \\
\hline Egalitarian Dimension & v2x_egal & $\begin{array}{l}\text { The egalitarian component is higher in countries which } \\
\text { reduce the barriers that ordinary people face, when try- } \\
\text { ing to exercise their formal rights. It is thus higher in } \\
\text { countries where resources and rights are judged to be dis- } \\
\text { tributed equally across social groups, and where this allo- } \\
\text { cation meets their basic needs. }\end{array}$ \\
\hline & & \\
\hline
\end{tabular}


Table 2: Variables Testing Key Accounts of Democratization

\section{Endogenous}

Modernization

Redistributivst

Class-Based
GDP per capita, Growth Rate, Urbanity, Educational Attainment Income Inequality

Landlord Power, Disruptive Capacity

\section{Exogenous}

Diffusion

Colonial Legacy

Oil

Population

Ethnic Minority

Institutional and Political History

Regional Average of Democracy Score, Globalization

Colonial Dummies, Colonial Duration

Oil Production Per Capita

Population

Ethnic Fractionalization, Excluded Population

Democratic Experience, Character of Authoritarian Regime

\section{Transition-Based}

Contentious Mobilization

Years of Pro-Democratic Mobilization Leading to Transition 
Table 3: In-Sample Descriptive Statistics

\begin{tabular}{l|lll}
\hline & Average & SD & Within SD \\
\hline
\end{tabular}

\section{Dependent Variables}

\begin{tabular}{l|lll} 
Deliberative Dimension & 74.70 & 18.43 & 6.49 \\
Participatory Dimension & 54.60 & 11.95 & 4.05 \\
Egalitarian Dimension & 61.86 & 20.95 & 2.95
\end{tabular}

\section{Independent Variables}

\begin{tabular}{l|rrr} 
Unarmed Mobilization & 2.20 & 2.63 & 0.12 \\
Armed Mobilization & 1.98 & 5.56 & 0.00 \\
GDP per capita (log) & 8.56 & 0.88 & 0.15 \\
Growth Rate & 0.02 & 0.04 & 0.04 \\
Educational Attainment & 6.82 & 2.60 & 0.66 \\
Urbanity & 29.72 & 14.59 & 1.52 \\
Income Inequality & 41.66 & 9.14 & 1.91 \\
Landlord Power & 24.26 & 15.17 & 5.03 \\
Disruptive Capacity & 16.29 & 5.63 & 1.67 \\
Oil Production per capita & 0.24 & 0.54 & 0.04 \\
Population (log) & 16.55 & 1.13 & 0.10 \\
Globalization & 61.49 & 32.88 & 11.30 \\
Colonial Duration & 164.44 & 144.55 & 0.00 \\
Democratic Experience & 7.87 & 9.51 & 0.53 \\
Excluded Population & 0.13 & 0.15 & 0.01 \\
Ethnic Fractionalization & 0.32 & 0.26 & 0.00 \\
Post-Military Rule & 0.52 & 0.50 & 0.02 \\
Post-Personalistic Rule & 0.38 & 0.48 & 0.03 \\
Post-Party Rule & 0.21 & 0.41 & 0.00 \\
Civil Society Pre-Mob. & 29.23 & 20.97 & 1.21 \\
Civil Liberties During Mob. & 42.48 & 19.14 & 1.06 \\
\hline
\end{tabular}

This table presents the average, standard deviation, and average within-country standard deviation ('Within SD') of each variable included in our preferred specifications. By average within-country standard deviation we refer to the average of the within-country standard deviations in our sample (i.e. $\frac{\sum_{i=1}^{N} S D_{i}}{N}$, where $S D_{i}$ is the standard deviation of a given variable in country $i$ ). 
Table 4: Long-Run Estimates, Main Outcomes

\begin{tabular}{|c|c|c|c|}
\hline & Deliberative & Participatory & Egalitarian \\
\hline \multicolumn{4}{|l|}{ Long-Run Multiplier } \\
\hline Unarmed Mobilization & $0.582^{* *}$ & $0.413^{* *}$ & $0.252^{* *}$ \\
\hline Armed Mobilization & $\begin{array}{c}-0.144 \\
{[-0.37 \text { to } 0.05]}\end{array}$ & $\begin{array}{c}-0.010 \\
{[-0.18 \text { to } 0.22]}\end{array}$ & {$\left[\begin{array}{c}0.012 \\
{[-0.12 \text { to } 0.11]}\end{array}\right.$} \\
\hline GDP per capita (log) & $\begin{array}{c}-0.003 \\
{[-0.45 \text { to } 0.4]}\end{array}$ & $\begin{array}{c}-0.192 \\
{[-0.79 \text { to } 0.22]}\end{array}$ & $\begin{array}{c}-0.189 \\
{[-0.45 \text { to } 0.11]}\end{array}$ \\
\hline Growth Rate & {$[-0.11$ to 0.02$]$} & $\begin{array}{c}-0.098^{+} \\
{[-0.21 \text { to } 0.01]}\end{array}$ & $\begin{array}{c}-0.007 \\
{[-0.08 \text { to } 0.04]}\end{array}$ \\
\hline Educational Attainment & $\begin{array}{c}-0.654^{* *} \\
{[-1.37 \text { to }-0.19]}\end{array}$ & $\begin{array}{c}-0.493^{*} \\
{[-0.94 \text { to }-0.04]}\end{array}$ & $\begin{array}{c}0.237 \\
{[-0.15 \text { to } 0.52]}\end{array}$ \\
\hline Urbanity & $\begin{array}{c}0.066 \\
{[-0.46 \text { to } 0.53]}\end{array}$ & $\begin{array}{c}0.267 \\
{[-0.16 \text { to } 0.84]}\end{array}$ & $\begin{array}{c}0.202 \\
{[-0.07 \text { to } 0.41]}\end{array}$ \\
\hline Income Inequality & $\begin{array}{c}-0.238^{*} \\
{[-0.46 \text { to }-0.01]}\end{array}$ & $\begin{array}{c}-0.124 \\
{[-0.55 \text { to } 0.22]}\end{array}$ & $\begin{array}{c}-0.171^{+} \\
{[-0.4 \text { to } 0.03]}\end{array}$ \\
\hline Landlord Power & $\begin{array}{c}-0.207 \\
{[-0.48 \text { to } 0.07]}\end{array}$ & $\begin{array}{c}-0.255^{+} \\
{[-0.54 \text { to } 0.02]}\end{array}$ & $\begin{array}{c}-0.298^{* *} \\
{[-0.49 \text { to }-0.14]}\end{array}$ \\
\hline Disruptive Capacity & $\begin{array}{c}0.163^{+} \\
{[-0.03 \text { to } 0.4]}\end{array}$ & $\begin{array}{c}0.340^{* *} \\
{[0.1 \text { to } 0.69]}\end{array}$ & $\begin{array}{c}0.065 \\
{[-0.04 \text { to } 0.16]}\end{array}$ \\
\hline Oil Production per capita & $\begin{array}{c}0.365^{* *} \\
{[0.22 \text { to } 0.56]}\end{array}$ & $\begin{array}{c}0.406^{* *} \\
{[0.17 \text { to } 0.77]}\end{array}$ & $\begin{array}{c}0.283^{* *} \\
{[0.13 \text { to } 0.48]}\end{array}$ \\
\hline Population (log) & $\begin{array}{c}-0.281^{*} \\
{[-0.47 \text { to }-0.04]}\end{array}$ & $\begin{array}{c}-0.350^{* *} \\
{[-0.67 \text { to }-0.11]}\end{array}$ & $\begin{array}{c}-0.381^{* *} \\
{[-0.57 \text { to }-0.21]}\end{array}$ \\
\hline Globalization & $\begin{array}{c}0.193^{*} \\
{[0.02 \text { to } 0.43]}\end{array}$ & {$\left[\begin{array}{c}-0.125 \\
{[-0.39 \text { to } 0.14]}\end{array}\right.$} & $\begin{array}{c}0.053 \\
{[-0.05 \text { to } 0.17]}\end{array}$ \\
\hline Colonial Duration & $\begin{array}{c}0.048 \\
{[-0.23 \text { to } 0.33]}\end{array}$ & $\begin{array}{c}-0.501^{* *} \\
{[-0.84 \text { to }-0.16]}\end{array}$ & $\begin{array}{c}-0.094 \\
{[-0.32 \text { to } 0.16]}\end{array}$ \\
\hline Democratic Experience & $\begin{array}{c}0.423^{* *} \\
{[0.17 \text { to } 0.79]}\end{array}$ & $\begin{array}{c}0.136 \\
{[-0.27 \text { to } 0.46]}\end{array}$ & $\begin{array}{c}0.094 \\
{[-0.09 \text { to } 0.35]}\end{array}$ \\
\hline Excluded Population & {$\left[\begin{array}{c}-0.155 \\
{[-0.4 \text { to } 0.06]}\end{array}\right.$} & $\begin{array}{c}-0.285^{*} \\
{[-0.6 \text { to }-0.01]}\end{array}$ & $\begin{array}{c}-0.018 \\
{[-0.1 \text { to } 0.07]}\end{array}$ \\
\hline Ethnic Fractionalization & $\begin{array}{c}0.235 \\
{[-0.07 \text { to } 0.55]}\end{array}$ & $\begin{array}{c}0.181 \\
{[-0.14 \text { to } 0.49]}\end{array}$ & $\begin{array}{c}0.005 \\
{[-0.12 \text { to } 0.16]}\end{array}$ \\
\hline Post-Military Rule & $\begin{array}{c}-0.259 \\
{[-0.92 \text { to } 0.25]}\end{array}$ & {$\left[\begin{array}{c}-0.065 \\
{[-0.76 \text { to } 0.73]}\end{array}\right.$} & $\begin{array}{c}0.092 \\
{[-0.35 \text { to } 0.53]}\end{array}$ \\
\hline Post-Personalistic Rule & $\begin{array}{c}0.138 \\
{[-0.46 \text { to } 0.64]}\end{array}$ & $\begin{array}{c}-0.059 \\
{[-0.52 \text { to } 0.5]}\end{array}$ & $\begin{array}{c}0.128 \\
{[-0.2 \text { to } 0.48]}\end{array}$ \\
\hline Post-Party Rule & $\begin{array}{c}0.947^{* *} \\
{[0.48 \text { to } 1.43]}\end{array}$ & $\begin{array}{c}0.422 \\
{[-0.14 \text { to } 1.02]}\end{array}$ & $\begin{array}{c}0.240 \\
{[-0.16 \text { to } 0.69]}\end{array}$ \\
\hline Civil Society Pre-Mob. & $\begin{array}{c}0.130 \\
{[-0.15 \text { to } 0.4]}\end{array}$ & $\begin{array}{c}0.701^{* *} \\
{[0.39 \text { to } 1.08]}\end{array}$ & $\begin{array}{c}0.050 \\
{[-0.17 \text { to } 0.31]}\end{array}$ \\
\hline Civil Liberties During Mob. & $\begin{array}{c}-0.156 \\
{[-0.41 \text { to } 0.11]}\end{array}$ & $\begin{array}{c}-0.255^{+} \\
{[-0.56 \text { to } 0.05]}\end{array}$ & $\begin{array}{c}0.050 \\
{[-0.15 \text { to } 0.23]}\end{array}$ \\
\hline Deliberative Dimension (Reg. Avg.) & $\begin{array}{c}0.149 \\
{[-0.14 \text { to } 0.41]}\end{array}$ & & \\
\hline Participatory Dimension (Reg. Avg.) & & $\begin{array}{c}0.412 \\
{[-0.23 \text { to } 1.11]}\end{array}$ & \\
\hline Egalitarian Dimension (Reg. Avg.) & & & $\begin{array}{c}0.346^{*} \\
{[0.05 \text { to } 0.81]}\end{array}$ \\
\hline \multicolumn{4}{|l|}{ Model Info } \\
\hline Observations & 944 & 944 & 944 \\
\hline Countries & 55 & 55 & 55 \\
\hline Range & $1957-2008$ & $1957-2008$ & $1957-2008$ \\
\hline Avg. $N_{i}$ & 17.2 & 17.2 & 17.2 \\
\hline Colonizer Dummies & Yes & Yes & Yes \\
\hline Country-Level & $\mathrm{RE}$ & $\mathrm{RE}$ & $\mathrm{RE}$ \\
\hline Region-Level & $\mathrm{FE}$ & $\mathrm{FE}$ & $\mathrm{FE}$ \\
\hline Year-Level & $\mathrm{FE}$ & $\mathrm{FE}$ & $\mathrm{FE}$ \\
\hline Adj. $R^{2}$ & 0.825 & 0.920 & 0.967 \\
\hline
\end{tabular}

This table reports long-run estimates from our preferred models. As discussed in the main text and in Section B of the Appendix, the inclusion of a lag of the dependent variable on the right-hand side of our models permits calculation of the cumulative (and not just immediate) impact of a change in a given independent variable. Note that each of these estimates is standardized. It represents the impact of a SD-sized change in the independent variable on the relevant variable, also in standard deviations. Each column of this table presents estimates from models with a different dependent variable. Our favored specification thus includes each of the controls listed along the left-hand side of the table, as well as a variety of other controls indicated in 'Model Info' (dummies for the identity of a country's colonial ruler, country-level random effects, region-level fixed effects, and year-level fixed effects). As explained in Section B of the Appendix, due to the difficulty of calculating standard errors analytically, we report $95 \%$ confidence intervals (and we use 90\%, 95\% and $99 \%$ confidence intervals to compute the corresponding level of statistical significance). 
Figure 1: Estimated Gains from Mobilization by Years Elapsed

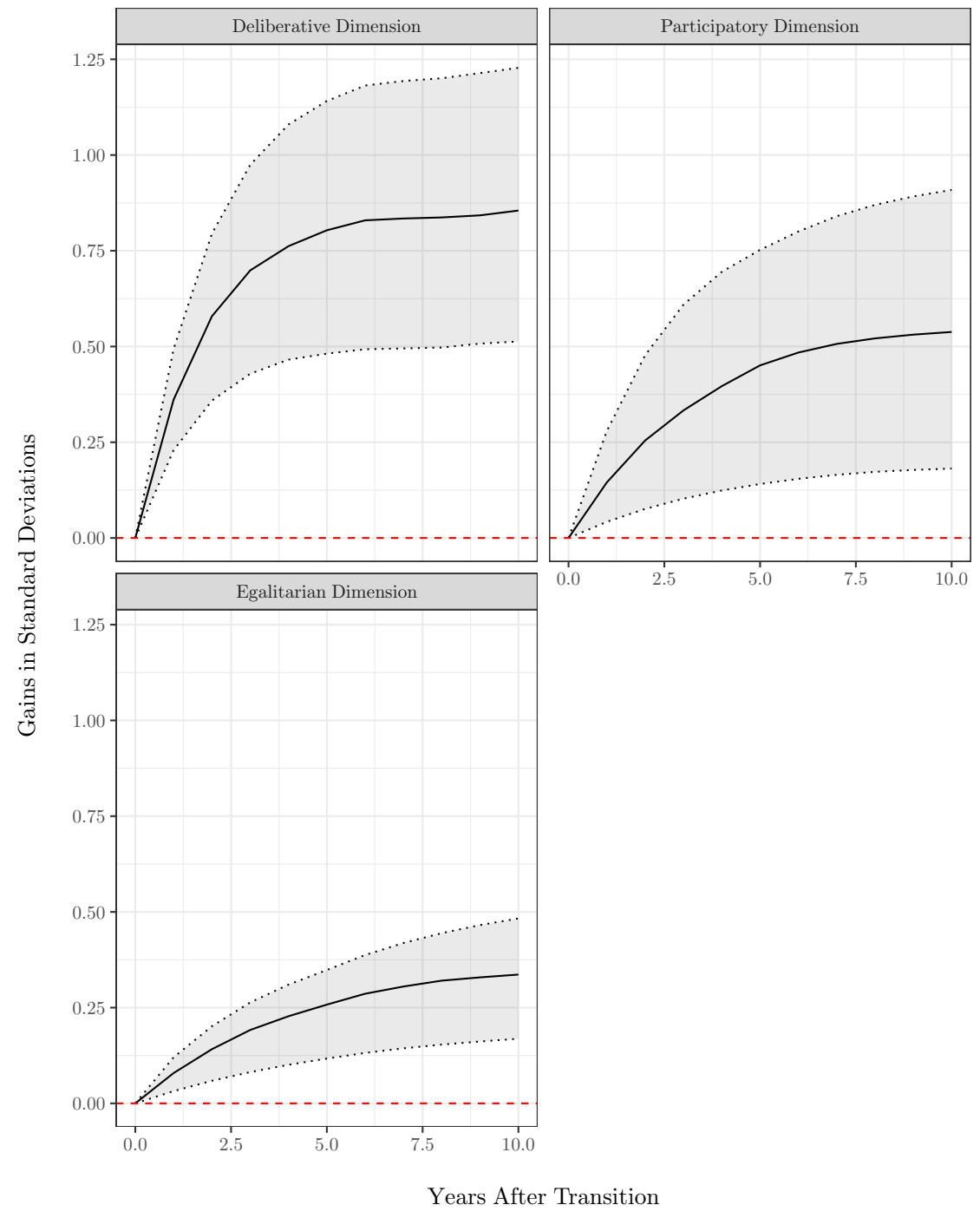

This figure illustrates the estimated aggregate impact of mobilization on democratic deepening, as measured by the predicted gap in democratic gains made in a world in which all transitions unfolded amidst mobilizations of 4.0 years, which is the $90^{\text {th }}$ percentile value of all post-1950 pro-democratic mobilizations, and a world in which all transitions unfolded amidst quiescence. Section $\mathrm{C}$ of the Appendix describes our methods and the results in more detail. The y-axis denotes the average difference in gains made under these two scenarios (in standard deviations of the dependent variable), and the x-axis denotes the number of years that have elapsed since transition. The solid line plots the average size of gains made across all spells that have survived a given number of years since transition, while the shaded area spans a $95 \%$ confidence interval for this average. 


\section{Online Appendix}

\section{A Robustness Checks}

As illustrated in Figure 2, we conducted a wide array of robustness checks. For reference, Figure 2 displays the statistical significance of all relevant covariates under all the alternative models we considered. For sake of brevity, we here focus on the robustness of our key result: the impact of prolonged unarmed mobilization on democratic deepening.

In total, we consider 21 alternative models, meaning that there are 63 total estimates to consider (i.e., one for each dependent variable). To summarize, it is only in 8 cases that our key hypothesis is not statistically significant at $\alpha=0.10$ or below. In all 8 of these cases the sign remains positive, and we have strong reasons to prefer the specification we discuss in the main paper.

One set of robustness checks examines our choice of independent variable. We found no evidence that our estimates are driven by campaigns of outlying length. Estimates are unchanged when we drop the longest campaign in our sample (South Africa in 1994), or when we use the natural log of campaign length. One might argue that strength of a movement is better approximated by considering years in which movements exist but do not actively mobilize (as in Poland's Solidarity, mid 1980s), so we constructed an alternative coding scheme that counts both years of public protest as well as years of organizing or abeyance. We also constructed an alternative measure of pretransition mobilization which codes all violent and nonviolent campaigns during the 20th century (Chenoweth and Lewis 2013). In both cases, our key estimates remain statistically significant at conventional levels. Separately, we replaced our measure of the duration of mobilization with a dummy variable denoting the existence of a campaign ('Campaign Dummies'). Here we find that the simple existence of a nonviolent campaign is not a consistently significant predictor of deepening in all five democratic dimensions, even though estimates are still all positive. This result thus affirms the importance of measuring not just the presence of contention but also its duration.

The removal or addition of other controls leaves results unchanged, with a single exception. When we employ a sparse specification and retain our truncated sample, we find that our estimate of the impact of unarmed mobilization on egalitarian democracy is positive but not statistically significant. When we use the same specification on a larger and more diverse sample, the estimate is statistically significant. Otherwise, results are unchanged. The inclusion of four lags (rather than one) of the dependent variable makes no difference to our preferred specification, suggesting that a single lag captures the dynamic behavior of these series reasonably well. Neither do our results seem to be driven by measures of a country's membership in international governmental organizations, or the proportion of a country's trade conducted with the US, the EU, China or Russia. These results suggest that the coincidence of sustained mobilizations and democratic deepening is not an artifact of international linkages. Nor does it matter how we modify the set of pre-transition controls we include: whether we add a measure of state fiscal capacity or alternative measures of state repressiveness or permissiveness towards civil society.

The results are also robust to including all post-WWII transitions from before 1950, or to excluding all transitions that we have not had much time to observe (i.e., those which happened after 2000). We also ran the models using an alternative measure of democracy (Cheibub, Gandhi, and Vreeland 2010) to define our universe of cases; each of the estimates is positive and statistically significant. Finally, as discussed already, we also estimate specifications which include country fixed-effects. In the first ('Dem. Years, Country Fixed Effects' in Figure 2), we replace the random-effects in our preferred model with fixed effects, but change nothing else. While all estimates are still positive, they are also generally more imprecise - significant in the deliberative dimension, but not in the egalitarian or participatory dimensions. Given the absence of within-country variation in our key independent variable, this imprecision is not surprising. For this reason, we also estimate country fixed-effects 
models on an expanded sample (all years for all countries in our sample, whether democracies or dictatorships). In effect, these models ask: over the post- WWII world, were countries which experienced sustained unarmed mobilizations more democratic during the subsequent democratization episode than when dictatorships or when in democratic episodes which were preceded by shorter or negligible contentious mobilizations? These models are very similar to those estimated by Haggard and Kaufman (2016: Chp. 5) The estimated impact of mobilization on participatory democracy is statistically significant. It is positive though still not significant in the case of egalitarian democracy.

\section{B Long-Run Multiplier}

As is well-known, the specification described in the main text permits the calculation of both immediate (or short-run) effects on the dependent variable, as well as persistent (or long-run) effects. As (De Boef and Keele 2008: pp.191-192) explain, calculating the standard error of this long-run estimate is not straightforward, since the long-run multiplier is the ratio of two (or more) coefficients. It is possible to directly estimate this uncertainty using the Bewley transformation. It is also possible to estimate it by simulation, which is how we proceeded in this paper. We simulated 10,000 draws from the relevant variance-covariance matrix (adjusted for clustering at the country level), and calculated a distribution for the long-run multipliers of interest. We calculate a $95 \%$ confidence interval for the estimate by computing the 2.5th and 97.5 th percentiles of this distribution. This is our preferred gauge of uncertainty, which is why we report confidence intervals rather than standard errors.

\section{Counterfactuals}

\section{C.1 Predictions}

To generate predictions from the model discussed in the text, we had to account for the inclusion of a lag of the dependent variable on the right-hand side of the Model described in the main text. Predicted values at time $t$ enter as regressors for predictions at time $t+1$, which requires that predictions be generated sequentially rather than all at once. To do this, we looped through each democratic spell and counterfactual, and predicted outcomes sequentially for all years that this spell entered our regression sample. This approach is very similar to that used by Lin and TomaskovicDevey (2013) in their analysis of financialization and inequality, except that they estimate errorcorrection models, whereas here we have estimated auto-regressive distributed lag models.

We make some effort to capture the standard errors associated with this prediction. After all, the $\beta$ 's are not at all quantities about which we are certain, and so neither are any derivative predictions. We estimate the errors associated with these predictions by drawing 100 samples from $N(\beta, \Omega)$, where $\beta$ is the vector of coefficient estimates, and $\Omega$ is the associated variance-covariance matrix. This follows the recommendations of King, Tomz, and Wittenberg (2000).

Note that because we fit the random-effects model by transforming the data first (using the plm package in R), we do not have estimates of the country-specific intercepts. These fall into the error term. As a result, these terms do not figure in our predictions, or in the associated estimates of uncertainty. This is not ideal, but it suffices for our purpose here, which is to illustrate the magnitude of the impact of mobilization implied by our estimates.

\section{C.2 Counterfactual Trajectories}

As we mention in the main text, even in a world in which all transitions were stage-managed, elitedriven affairs, democracies would have made progress. In other words, even as mass mobilization had 
a discernible, significant impact, other factors certainly mattered alongside. This invites estimates of the share of progress due to mass mobilization. Would democracies have progressed more-or-less as much as in a quiescent world as in a mobilized one? This is another way of asking whether mass mobilization really mattered.

One can estimate the share of progress due to mobilization in two ways: either by gauging the extent to which progress would have been muted in a quiescent world, or the extent to which it would have been amplified in a world filled with mass mobilizations. We calculated the first by measuring progress made under quiescence as a percentage of the progress made in the observed world, and subtracting from 100. We calculated the second by measuring the additional progress made in a world of mass mobilization as a percentage of progress made in the observed world, and subtracting 100. Figure 3 illustrates both, ten years out from transition. ${ }^{1}$ The left-hand panel illustrates the percentage of average democratic progress that would have vanished in the absence of mobilizations ('Losses from Quiescence'), while the right-hand panel illustrates the additional progress witnessed in a universe of mass mobilizations ('Gains from Mobilization'). Again, the overall lesson is the same: progress due to mobilization is far from trivial in any of the three dimensions. By either measure, mobilization accounts for anywhere from $15 \%$ to almost $60 \%$ of the progress made after transition.

1. These quantities can be calculated any number of years after transition, so this choice of ten years is arbitrary. (Recall that we observe democratic spells for varying amounts of time after transition, either because they fell back into dictatorship or because they transitioned to democracy at varying remove from the end of our sample in 2010. As a result, the number of democracies observed falls in proportion to years elapsed.) We choose to summarize progress after ten years because this is the median length of all democratic spells. Results are not substantively different if a different year is chosen. Note also that, in each scenario, some of the raw progress observed since transition could be a function of the shifting composition of the sample (since democracies predisposed to progress are also probably more likely to stay in our sample). This is not a problem for our discussion in the main text, since there we compare scenarios in which the sample changes in the same way each year. But it could skew interpretation of raw progress (as plotted in Figure 4), so that figure should be interpreted with this caveat in mind. 
Table 5: Short-Run Estimates, Main Outcomes

\begin{tabular}{|c|c|c|c|}
\hline & Deliberative & Participatory & Egalitarian \\
\hline \multicolumn{4}{|l|}{ Lagged Dep. Var } \\
\hline Deliberative Dimension $_{t-1}$ & $\begin{array}{c}0.032^{* *} \\
(0.004)\end{array}$ & & \\
\hline 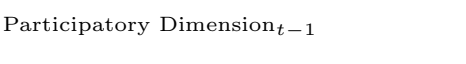 & & $\begin{array}{c}0.063^{* *} \\
(0.004)\end{array}$ & \\
\hline Egalitarian Dimension $_{t-1}$ & & & $\begin{array}{l}0.038^{* *} \\
(0.002)\end{array}$ \\
\hline \multicolumn{4}{|l|}{ Short-Run Impact } \\
\hline Unarmed Mobilization & $\begin{array}{l}0.235^{* *} \\
(0.059)\end{array}$ & $\begin{array}{l}0.104^{*} \\
(0.042)\end{array}$ & $\begin{array}{c}0.050^{* *} \\
(0.017)\end{array}$ \\
\hline Armed Mobilization & $\begin{array}{l}-0.058 \\
(0.040)\end{array}$ & $\begin{array}{l}-0.002 \\
(0.024)\end{array}$ & $\begin{array}{c}0.002 \\
(0.010)\end{array}$ \\
\hline GDP per capita $(\log )_{t-1}$ & $\begin{array}{l}-0.001 \\
(0.083)\end{array}$ & $\begin{array}{l}-0.049 \\
(0.056)\end{array}$ & $\begin{array}{l}-0.038 \\
(0.027)\end{array}$ \\
\hline Growth Rate $_{t-1}$ & $\begin{array}{l}-0.022 \\
(0.014)\end{array}$ & $\begin{array}{r}-0.025^{+} \\
(0.014)\end{array}$ & $\begin{array}{l}-0.001 \\
(0.005)\end{array}$ \\
\hline Educational Attainment $_{t-1}$ & $\begin{array}{c}-0.265^{* *} \\
(0.091)\end{array}$ & $\begin{array}{l}-0.126^{*} \\
(0.061)\end{array}$ & $\begin{array}{l}0.048 \\
(0.035)\end{array}$ \\
\hline Urbanity $_{t-1}$ & $\begin{array}{c}0.029 \\
(0.096)\end{array}$ & $\begin{array}{c}0.068 \\
(0.057)\end{array}$ & $\begin{array}{c}0.041 \\
(0.025)\end{array}$ \\
\hline Income Inequality $t-1$ & $\begin{array}{l}-0.097^{*} \\
(0.046)\end{array}$ & $\begin{array}{l}-0.030 \\
(0.045)\end{array}$ & $\begin{array}{r}-0.034^{+} \\
(0.020)\end{array}$ \\
\hline Landlord Power $t-1$ & $\begin{array}{l}-0.083 \\
(0.054)\end{array}$ & $\begin{array}{r}-0.064^{+} \\
(0.035)\end{array}$ & $\begin{array}{c}-0.059^{* *} \\
(0.020)\end{array}$ \\
\hline Disruptive Capacity $_{t-1}$ & $\begin{array}{l}0.065^{+} \\
(0.040)\end{array}$ & $\begin{array}{c}0.085^{* *} \\
(0.030)\end{array}$ & $\begin{array}{c}0.013 \\
(0.010)\end{array}$ \\
\hline Oil Production per capita $t_{-1}$ & $\begin{array}{l}0.147^{* *} \\
(0.030)\end{array}$ & $\begin{array}{l}0.102^{* *} \\
(0.028)\end{array}$ & $\begin{array}{c}0.057^{* *} \\
(0.018)\end{array}$ \\
\hline Population $(\log )_{t-1}$ & $\begin{array}{l}-0.113^{*} \\
(0.051)\end{array}$ & $\begin{array}{c}-0.088^{* *} \\
(0.030)\end{array}$ & $\begin{array}{c}-0.077^{* *} \\
(0.024)\end{array}$ \\
\hline Globalization $_{t-1}$ & $\begin{array}{l}0.078^{*} \\
(0.035)\end{array}$ & $\begin{array}{l}-0.032 \\
(0.033)\end{array}$ & $\begin{array}{c}0.011 \\
(0.010)\end{array}$ \\
\hline Colonial Duration & $\begin{array}{c}0.020 \\
(0.055)\end{array}$ & $\begin{array}{c}-0.127^{* *} \\
(0.048)\end{array}$ & $\begin{array}{l}-0.019 \\
(0.022)\end{array}$ \\
\hline Democratic Experience & $\begin{array}{c}0.171^{* *} \\
(0.050)\end{array}$ & $\begin{array}{c}0.034 \\
(0.046)\end{array}$ & $\begin{array}{c}0.019 \\
(0.019)\end{array}$ \\
\hline Excluded Population $_{t-1}$ & $\begin{array}{l}-0.062 \\
(0.045)\end{array}$ & $\begin{array}{c}-0.072^{*} \\
(0.036)\end{array}$ & $\begin{array}{l}-0.004 \\
(0.007)\end{array}$ \\
\hline Ethnic Fractionalization & $\begin{array}{c}0.094 \\
(0.063)\end{array}$ & $\begin{array}{c}0.046 \\
(0.039)\end{array}$ & $\begin{array}{c}0.001 \\
(0.012)\end{array}$ \\
\hline Post-Military Rule & $\begin{array}{l}-0.105 \\
(0.110)\end{array}$ & $\begin{array}{l}-0.016 \\
(0.091)\end{array}$ & $\begin{array}{l}0.018 \\
(0.039)\end{array}$ \\
\hline Post-Personalistic Rule & $\begin{array}{c}0.055 \\
(0.109)\end{array}$ & $\begin{array}{l}-0.013 \\
(0.062)\end{array}$ & $\begin{array}{c}0.026 \\
(0.031)\end{array}$ \\
\hline Post-Party Rule & $\begin{array}{l}0.383^{* *} \\
(0.107)\end{array}$ & $\begin{array}{c}0.108 \\
(0.072)\end{array}$ & $\begin{array}{c}0.048 \\
(0.039)\end{array}$ \\
\hline Civil Society Pre-Mob. & $\begin{array}{c}0.052 \\
(0.055)\end{array}$ & $\begin{array}{l}0.176^{* *} \\
(0.046)\end{array}$ & $\begin{array}{c}0.010 \\
(0.020)\end{array}$ \\
\hline Civil Liberties During Mob. & $\begin{array}{l}-0.064 \\
(0.053)\end{array}$ & $\begin{array}{r}-0.064^{+} \\
(0.038)\end{array}$ & $\begin{array}{c}0.010 \\
(0.017)\end{array}$ \\
\hline Deliberative Dimension (Reg. Avg.) $t-1$ & $\begin{array}{c}0.060 \\
(0.056)\end{array}$ & & \\
\hline Participatory Dimension (Reg. Avg.) $)_{t-1}$ & & $\begin{array}{c}0.104 \\
(0.080)\end{array}$ & \\
\hline Egalitarian Dimension (Reg. Avg. $)_{t-1}$ & & & $\begin{array}{l}0.069^{*} \\
(0.031)\end{array}$ \\
\hline
\end{tabular}

This table reports short-run estimates from our preferred models. In models which include lags of the dependent variable, short-run estimates are not useful gauges of practical significance (i.e. effect size), and the statistical significance of any given estimate is typically identifcal to the statistical significance of the corresponding long-run estimate. For these reasons, we relegate these estimates to the Appendix. Because standard errors for short-run estimates are easy to compute analytically, we report these rather than the confidence intervals reported in 4. 
Table 6: Democratic Regimes in Final Sample

\begin{tabular}{|c|c|c|c|c|}
\hline & Years When Democracy & \% Years in Sample & Unarmed Mob. & Armed Mob. \\
\hline Albania & $1992-2010$ & 58 & 3 & 0 \\
\hline \multirow[t]{2}{*}{ Argentina } & $1974-1976$ & 100 & 1 & 0 \\
\hline & $1984-2010$ & 93 & 7 & 0 \\
\hline Armenia & 1992-1994 & 0 & 4 & 0 \\
\hline Azerbaijan & 1993-1993 & 0 & 3 & 1 \\
\hline \multirow[t]{2}{*}{ Bangladesh } & 1991-2007 & 94 & 3 & 0 \\
\hline & 2009-2010 & 0 & 0 & 0 \\
\hline Benin & $1992-2010$ & 0 & 1 & 0 \\
\hline Bolivia & $1983-2010$ & 93 & 8 & 0 \\
\hline Brazil & $1986-2010$ & 92 & 6 & 0 \\
\hline Bulgaria & $1991-2010$ & 90 & 2 & 0 \\
\hline \multirow{2}{*}{ Burundi } & 1994-1996 & 0 & 0 & 3 \\
\hline & $2006-2010$ & 0 & 0 & 10 \\
\hline Central African Republic & 1994-2003 & 0 & 0 & 0 \\
\hline Chile & $1990-2010$ & 90 & 6 & 0 \\
\hline Colombia & $1959-2010$ & 96 & 1 & 0 \\
\hline Congo & 1993-1997 & 0 & 1 & 0 \\
\hline Croatia & $1992-2010$ & 53 & 0 & 0 \\
\hline Czech Republic & $1990-2013$ & 42 & 1 & 0 \\
\hline \multirow{2}{*}{ Dominican Republic } & $1963-1963$ & 0 & 0 & 0 \\
\hline & $1979-2010$ & 94 & 0 & 0 \\
\hline \multirow[t]{2}{*}{ Ecuador } & 1969-1970 & 100 & 1 & 0 \\
\hline & $1980-2010$ & 90 & 0 & 0 \\
\hline El Salvador & $1995-2010$ & 88 & 0 & 12 \\
\hline Estonia & $1992-2010$ & 53 & 5 & 0 \\
\hline Georgia & 2005-2010 & 0 & 2 & 0 \\
\hline \multirow{4}{*}{ Ghana } & $1957-1960$ & 0 & 4 & 0 \\
\hline & $1970-1972$ & 100 & 0 & 0 \\
\hline & $1980-1981$ & 100 & 2 & 0 \\
\hline & $2001-2010$ & 70 & 0 & 0 \\
\hline Greece & $1975-2010$ & 94 & 1 & 0 \\
\hline Guatemala & $1996-2010$ & 80 & 1 & 32 \\
\hline \multirow[t]{2}{*}{ Guinea-Bissau } & 2001-2002 & 0 & 0 & 0 \\
\hline & 2006-2010 & 0 & 0 & 0 \\
\hline \multirow[t]{4}{*}{ Haiti } & 1991-1991 & 100 & 4 & 0 \\
\hline & 1995-1999 & 0 & 0 & 0 \\
\hline & 2007-2010 & 0 & 0 & 1 \\
\hline & 1958-1963 & 0 & 0 & 0 \\
\hline \multirow{2}{*}{ Honduras } & $1972-1972$ & 100 & 0 & 0 \\
\hline & $1982-2010$ & 93 & 0 & 0 \\
\hline Hungary & $1991-2010$ & 90 & 0 & 0 \\
\hline Indonesia & $2000-2010$ & 82 & 2 & 0 \\
\hline Kenya & 2003-2010 & 75 & 2 & 0 \\
\hline Laos & 1954-1959 & 0 & 0 & 7 \\
\hline Latvia & $1992-2010$ & 53 & 5 & 0 \\
\hline Lebanon & 2006-2010 & 0 & 1 & 0 \\
\hline
\end{tabular}




\begin{tabular}{|c|c|c|c|c|}
\hline \multirow[t]{2}{*}{ Lesotho } & 1966-1970 & 0 & 0 & 0 \\
\hline & 1994-2010 & 41 & 1 & 0 \\
\hline Liberia & 2006-2010 & 0 & 0 & 4 \\
\hline Lithuania & $1992-2010$ & 53 & 4 & 0 \\
\hline Macedonia & $1992-2010$ & 0 & 0 & 0 \\
\hline Madagascar & 1994-2009 & 0 & 2 & 0 \\
\hline Malawi & $1995-2010$ & 88 & 1 & 0 \\
\hline Mali & $1993-2010$ & 72 & 2 & 0 \\
\hline Mauritania & 2008-2008 & 0 & 0 & 0 \\
\hline Mauritius & $1969-2010$ & 0 & 0 & 0 \\
\hline Mexico & 2001-2010 & 80 & 0 & 1 \\
\hline Moldova & 1992-2010 & 53 & 1 & 1 \\
\hline Mongolia & 1994-2010 & 88 & 1 & 0 \\
\hline Montenegro & 2007-2010 & 0 & 0 & 0 \\
\hline Myanmar & 1961-1962 & 0 & 0 & 0 \\
\hline \multirow[t]{2}{*}{ Nepal } & 1992-2002 & 100 & 1 & 0 \\
\hline & $2007-2010$ & 0 & 3 & 10 \\
\hline Nicaragua & 1991-2010 & 70 & 0 & 11 \\
\hline \multirow[t]{2}{*}{ Niger } & 1994-1996 & 0 & 2 & 0 \\
\hline & $2000-2010$ & 0 & 3 & 0 \\
\hline \multirow[t]{3}{*}{ Nigeria } & 1961-1966 & 0 & 2 & 0 \\
\hline & $1980-1983$ & 0 & 0 & 0 \\
\hline & $2000-2010$ & 0 & 3 & 0 \\
\hline \multirow[t]{3}{*}{ Pakistan } & $1972-1975$ & 75 & 3 & 0 \\
\hline & 1989-1999 & 100 & 0 & 0 \\
\hline & 2009-2010 & 0 & 1 & 0 \\
\hline \multirow[t]{3}{*}{ Panama } & 1953-1953 & 0 & 3 & 0 \\
\hline & $1956-1968$ & 0 & 0 & 0 \\
\hline & $1990-2010$ & 90 & 0 & 0 \\
\hline Paraguay & 1994-2010 & 88 & 0 & 0 \\
\hline \multirow[t]{4}{*}{ Peru } & 1957-1962 & 100 & 0 & 0 \\
\hline & 1964-1968 & 100 & 0 & 0 \\
\hline & 1981-1992 & 100 & 3 & 0 \\
\hline & 2002-2010 & 78 & 1 & 0 \\
\hline Philippines & $1987-2010$ & 92 & 4 & 18 \\
\hline Poland & 1990-2010 & 90 & 6 & 0 \\
\hline Portugal & $1977-2010$ & 94 & 3 & 0 \\
\hline Romania & 1991-2010 & 90 & 2 & 1 \\
\hline Russia & 1992-1993 & 0 & 5 & 0 \\
\hline Senegal & 2001-2010 & 80 & 0 & 0 \\
\hline Serbia & $2001-2010$ & 0 & 4 & 0 \\
\hline \multirow[t]{3}{*}{ Sierra Leone } & $1962-1967$ & 0 & 3 & 0 \\
\hline & 1997-1997 & 0 & 0 & 6 \\
\hline & 1999-2010 & 25 & 0 & 8 \\
\hline Slovakia & $1993-2010$ & 6 & 3 & 0 \\
\hline Slovenia & $1992-2010$ & 26 & 0 & 0 \\
\hline Somalia & 1961-1969 & 0 & 5 & 0 \\
\hline South Africa & $1995-2010$ & 88 & 13 & 7 \\
\hline \multirow[t]{2}{*}{ South Korea } & 1961-1961 & 100 & 1 & 0 \\
\hline & $1988-2010$ & 91 & 2 & 0 \\
\hline Spain & $1978-2010$ & 94 & 6 & 11 \\
\hline
\end{tabular}




\begin{tabular}{rr|c|cc} 
Sri Lanka & $1995-2010$ & 88 & 0 & 19 \\
Sudan & $1956-1958$ & 0 & 0 & 0 \\
& $1966-1969$ & 25 & 1 & 5 \\
Syria & $1987-1989$ & 0 & 1 & 4 \\
& $1955-1957$ & 0 & 1 & 0 \\
Taiwan & $1962-1962$ & 0 & 0 & 0 \\
Tanzania & $2001-2010$ & 0 & 0 & 0 \\
Thailand & $1961-1964$ & 0 & 0 & 0 \\
& $1976-1976$ & 100 & 1 & 0 \\
& $1989-1991$ & 100 & 0 & 0 \\
Togo & $1993-2006$ & 100 & 1 & 0 \\
Turkey & $2008-2010$ & 33 & 1 & 0 \\
& $1964-1967$ & 0 & 0 & 0 \\
Uganda & $1962-1980$ & 100 & 0 & 0 \\
Ukraine & $1984-2010$ & 93 & 0 & 0 \\
Uruguay & $1963-1966$ & 0 & 4 & 0 \\
Venezuela & $1992-2010$ & 53 & 2 & 0 \\
Zambia & $1985-2010$ & 92 & 1 & 0 \\
& $1959-2005$ & 100 & 3 & 0 \\
\hline
\end{tabular}


Table 7: List of Robustness and Sensitivity Checks

\begin{tabular}{r|l}
\hline & Model Detail \\
\hline (A) & Preferred \\
(B) & Campaign Dummies \\
(C) & Log Campaign Length \\
(D) & Drop Longest Campaign \\
(E) & Alternative Coding \\
(F) & NAVCO Coding \\
(G) & Sparse \\
(H) & Sparse, All Obs. \\
(I) & No Pre-Transition Controls \\
(J) & Pre-Transition Controls, Fiscal \\
(K) & Pre-Transition Controls, 5-Yr CL \\
(L) & Pre-Transition Controls, 10-Yr CL \\
(M) & Pre-Transition Controls, Repression \\
(N) & Four Lags of Dep. Var. \\
(O) & World Polity Vars \\
(P) & Trade Vars \\
(Q) & Includes Pre-1950 Transitions \\
(R) & Excludes Post-2000 Transitions \\
(S) & CGV-Based Spells \\
(T) & All Years, Country Fixed Effects \\
(U) & Dem Years, Country Fixed Effects \\
(V) & Drop Biggest Oil Producer \\
(W) & Drop Three Biggest Oil Producers \\
(X) & Sparse, Oil Only \\
\hline
\end{tabular}


Figure 2: Estimates from Robustness Checks
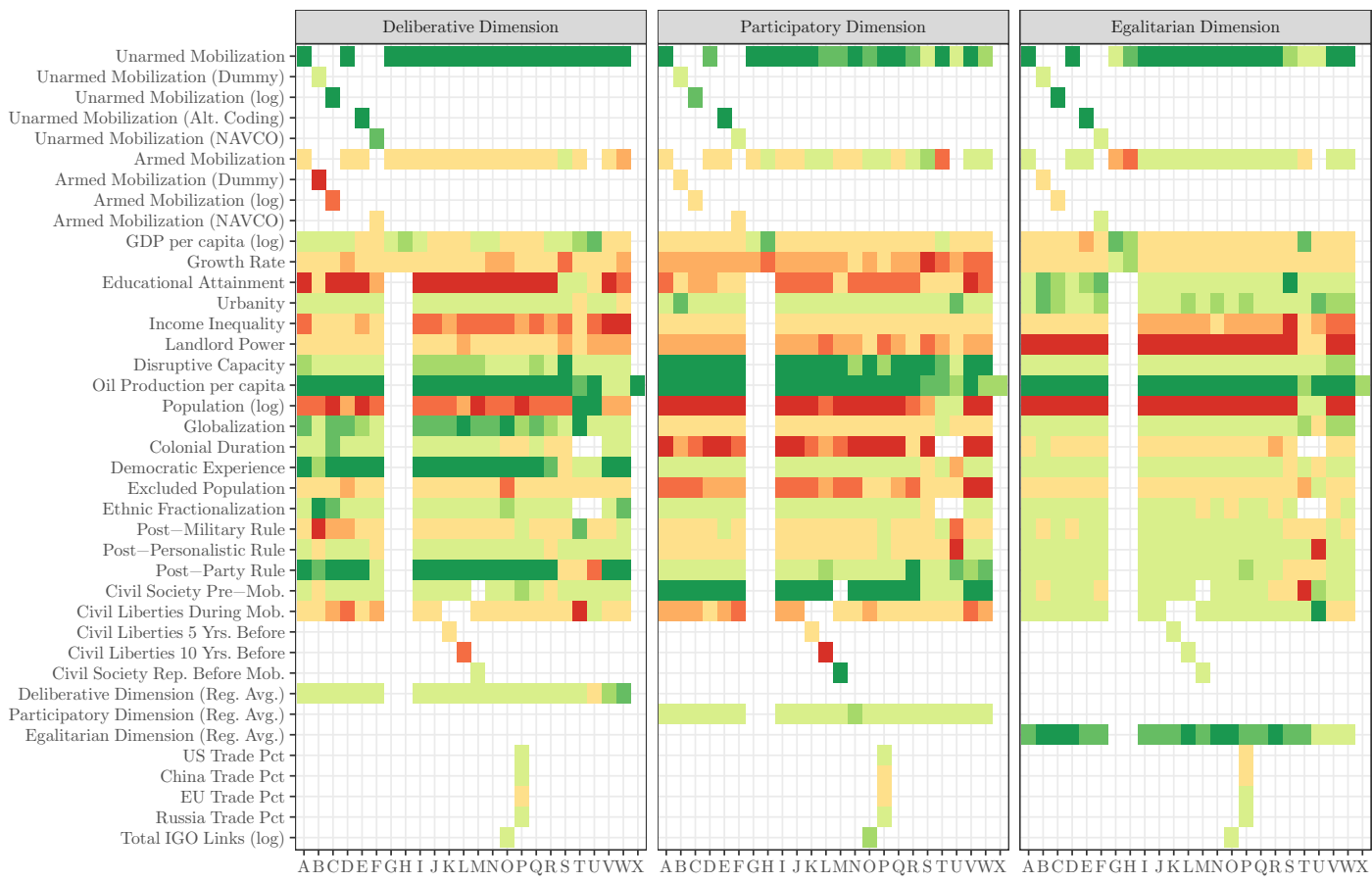

$\alpha=0.01, \beta<0$

$\alpha=0.05, \beta<0$

$\alpha=0.1, \beta<0$

$\beta<0$
$\beta>0$

$\alpha=0.1, \beta>0$

$\alpha=0.05, \beta>0$

$\alpha=0.01, \beta>0$

This figure illustrates results from the various robustness checks. The $\mathrm{x}$-axis denotes the robustness check (i.e. model) being considered. Table 7 translates. The y-axis denotes the covariate in question. (Where the tile is empty, this is because the covariate in question is not a part of the model in question.) As we discuss in more detail in Section A, the consistency of our estimates across specifications affirms our confidence in the main inference in this paper: that the length of unarmed mobilization prior to transition predicts subsequent democratic deepening. 


\section{Figure 3: Estimated Deepening by Counterfactual}

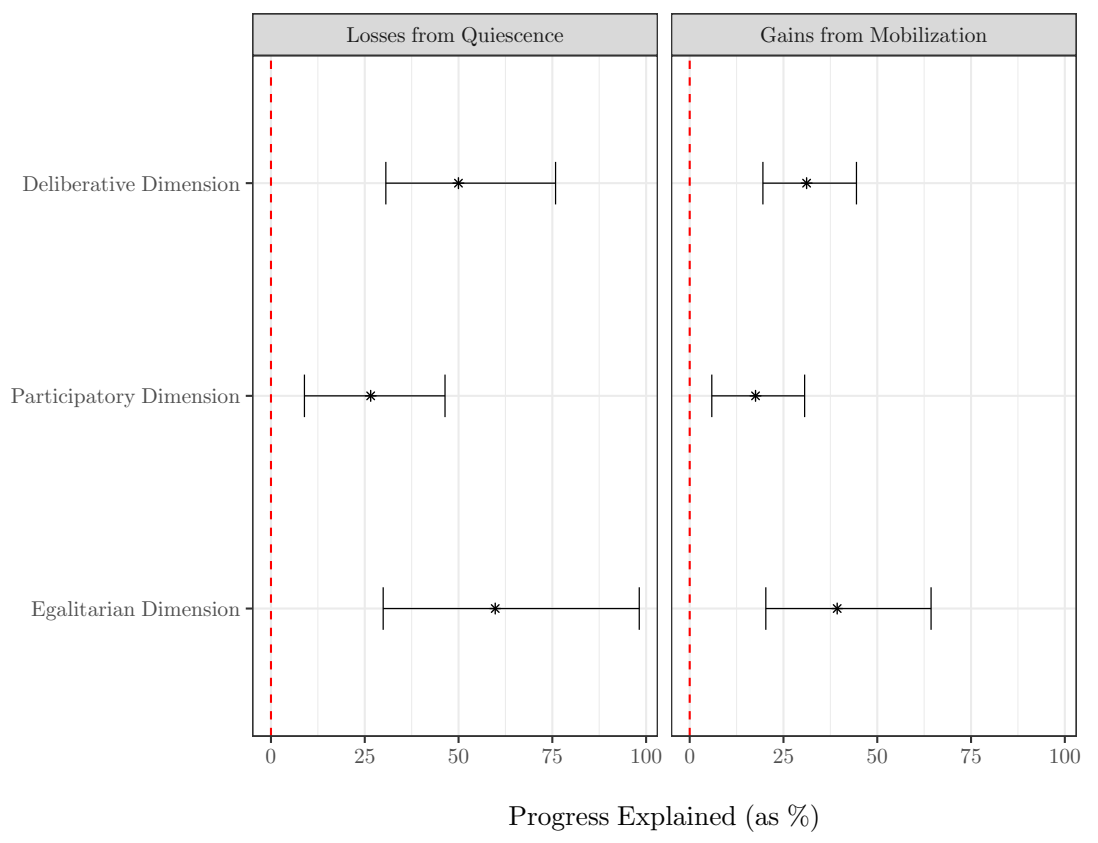

This figure presents two different estimates of the share of democratic deepening after 10 years which can be attributed to mobilization. The left-hand panel plots 'Losses from Quiescence', which are calculated as the progress made under quiescence as a percentage of the progress made in the observed world, subtracted from 100. This can be interpreted as the percentage of democratic deepening forgone in a world without mobilization. The right-hand panel plots 'Gains from Mobilization', which are calculated as the additional progress made in a world of mass mobilization as a percentage of observed progress, subtracting 100. This can be interpreted as the additional deepening that would have been witnessed in a world in which all democracies were detonated by mass mobilization. The points denote our estimate, and the error-bars a corresponding 95\% confidence interval. 
Figure 4: Predicted Aggregate Trajectories by Counterfactual

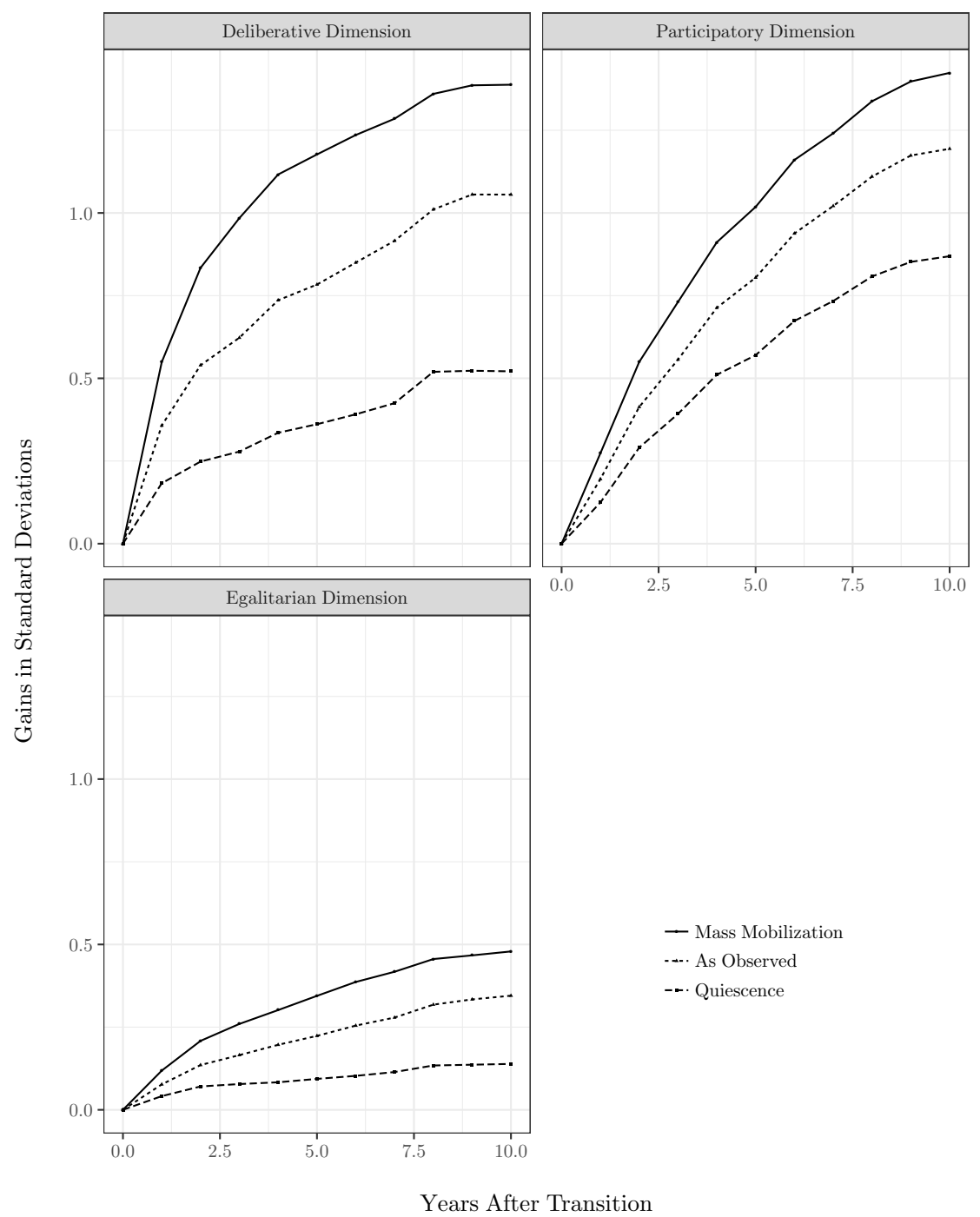

This figure illustrates the predicted gains made after after transition (averaged across all democratic spells) under each of three scenarios: (1) Mass Mobilization ('Unarmed Mobilization' set to 4.3 years); (2) As Observed ('Unarmed Mobilization' left as observed); (3) Quiescence ('Unarmed Mobilization) set to 0 years. (Section $\mathrm{C}$ of the Appendix describes our methods and the results in more detail). The y-axis denotes the average gains made in each scenario (in standard deviations of the dependent variable), and the $\mathrm{x}$-axis denotes the number of years that have elapsed since transition. Each line plots the average trajectory under a different scenario. 